\title{
The Aichi Biodiversity Targets: Achievements for marine conservation and priorities beyond 2020
}

\author{
Hannah Carr ${ }^{\text {Corresp., } 1}$, Marina Abas ${ }^{2}$, Loubna Boutahar ${ }^{3,4}$, Olivia N Caretti $^{5}$, Wing Yan Chan ${ }^{6,7}$, Abbie Chapman ${ }^{8,9}$, \\ Sarah Natasha de Mendonça ${ }^{10}$, Abigail Engleman ${ }^{11}$, Filippo Ferrario ${ }^{12}$, Kayelyn R Simmons ${ }^{5}$, Jana Verdura ${ }^{13}$, \\ Anna Zivian ${ }^{14}$ \\ ${ }^{1}$ The Joint Nature Conservation Committee, Peterborough, Cambridgeshire, UK \\ 2 Departamento de Ciencias Marinas y Costeras, Universidad Autónoma de Baja California Sur, La Paz, Baja California Sur, Mexico \\ 3 Faculty of Sciences, Mohammed V University in Rabat, Rabat, Morocco \\ 4 Laboratorío de Biología Marina, Departamento de Zoología, Universidad de Sevilla, Sevilla, Spain \\ 5 Department of Marine, Earth, \& Atmospheric Sciences, North Carolina State University, Raleigh, North Carolina, United States of America \\ 6 Australian Institute of Marine Science, Townsville, Queensland, Australia \\ 7 School of BioSciences, University of Melbourne, Melbourne, Victoria, Australia \\ 8 School of Ocean and Earth Science, University of Southampton, Southampton, Hampshire, United Kingdom \\ ${ }^{9}$ Centre for Biodiversity and Environment Research, University College London, London, United Kingdom \\ 10 Department of Oceanography, Dalhousie University, Halifax, Nova Scotia, Canada \\ 11 Department of Biological Sciences, Florida State University, Tallahassee, Florida, United States of America \\ 12 Québec Ocean and Département de Biologie, Université Laval, Québec, Canada \\ 13 Institut d'Ecologia Aquàtica, Facultat de Ciències, Universitat de Girona, Girona, Spain \\ 14 Ocean Conservancy, Santa Cruz, California, United States of America \\ Corresponding Author: Hannah Carr \\ Email address: hannah.carr@jncc.gov.uk
}

In 2010 the Conference of the Parties (COP) for the Convention on Biological Diversity revised and updated a Strategic Plan for Biodiversity 2011 - 2020, which included the Aichi Biodiversity Targets. Here a group of early career researchers mentored by senior scientists, convened as part of the $4{ }^{\text {th }}$ World Conference on Marine Biodiversity, reflects on the accomplishments and shortfalls under four of the Aichi Targets considered highly relevant to marine conservation: target 6 (sustainable fisheries), 11 (protection measures), 15 (ecosystem restoration and resilience) and 19 (knowledge, science and technology). We conclude that although progress has been made towards the targets, these have not been fully achieved for the marine environment by the 2020 deadline. The progress made, however, lays the foundations for further work beyond 2020 to work towards the 2050 Vision for Biodiversity. We identify key priorities that must be addressed to better enable marine biodiversity conservation efforts moving forward. 
1 The Aichi Biodiversity Targets: Achievements for marine conservation and priorities beyond 2020

2 Hannah Carr ${ }^{1}$, Marina Abas ${ }^{2}$, Loubna Boutahar 3,4 , Olivia N Caretti ${ }^{5}$, Wing Yan Chan ${ }^{6,7}$, Abbie S.

3 A. Chapman ${ }^{8,9}$, Sarah Natasha de Mendonça ${ }^{10}$, Abigail Engleman ${ }^{11}$, Filippo Ferrario ${ }^{12}$, Kayelyn

4 R Simmons $^{5}$, Jana Verdura ${ }^{13}$, \& Anna Zivian ${ }^{14}$.

5

$6{ }^{1}$ The Joint Nature Conservation Committee, Peterborough, Cambridgeshire, United Kingdom.

72 Departamento de Ciencias Marinas y Costeras, Universidad Autónoma de Baja California

8 Sur, La Paz, Baja California Sur, Mexico.

$9{ }^{3}$ Mohammed V University in Rabat, Faculty of Sciences, Rabat, Morocco.

$10{ }^{4}$ Laboratorío de Biología Marina, Departamento de Zoología, Universidad de Sevilla, Spain.

$11{ }^{5}$ Department of Marine, Earth, \& Atmospheric Sciences, North Carolina State University,

12 Raleigh, North Carolina, United States of America.

$13{ }^{6}$ Australian Institute of Marine Science, Townsville, Queensland, Australia.

$14{ }^{7}$ School of BioSciences, University of Melbourne, Victoria, Australia.

$15{ }^{8}$ School of Ocean and Earth Science, University of Southampton Waterfront Campus, National

16 Oceanography Centre, Southampton, Hampshire, United Kingdom.

$17{ }^{9}$ Centre for Biodiversity and Environment Research, University College London, London, UK.

$18{ }^{10}$ Department of Oceanography, Dalhousie University, Halifax, Nova Scotia, Canada.

$19{ }^{11}$ Department of Biological Sciences, Florida State University, Tallahassee, Florida, United

20 States of America.

$21{ }^{12}$ Québec Ocean and Département de Biologie, Université Laval, Québec, Canada.

$22{ }^{13}$ Institut d'Ecologia Aquàtica, Facultat de Ciències, Universitat de Girona, Spain.

2314 Ocean Conservancy, Santa Cruz, California, United States of America.

25 Corresponding Author:

26 Hannah Carr

27 Marine Ecosystems Team, The Joint Nature Conservation Committee, Monkstone House, City

28 Road, Peterborough, Cambridgeshire, PE1 1JY, United Kingdom

29 Email address: hannah.carr@jncc.gov.uk

30

31 Keywords: Aichi, Biodiversity, Target, 2020, Marine, Conservation, Priorities

Peer) reviewing PDF | (2019:07:39530:2:0:NEW 21 Jul 2020) 
32 Abstract

33 In 2010 the Conference of the Parties (COP) for the Convention on Biological Diversity revised

34 and updated a Strategic Plan for Biodiversity 2011 - 2020, which included the Aichi Biodiversity

35 Targets. Here a group of early career researchers mentored by senior scientists, convened as part

36 of the $4^{\text {th }}$ World Conference on Marine Biodiversity, reflects on the accomplishments and

37 shortfalls under four of the Aichi Targets considered highly relevant to marine conservation:

38 target 6 (sustainable fisheries), 11 (protection measures), 15 (ecosystem restoration and

39 resilience), and 19 (knowledge, science and technology). We conclude that although progress has

40 been made towards achieving the targets, these have not been fully achieved for the marine

41 environment by the 2020 deadline. The progress made, however, lays the foundations for further

42 work beyond 2020 to work towards the 2050 Vision for Biodiversity. We thus identify key

43 priorities that must be addressed to better enable marine biodiversity conservation efforts moving

44 forward.

45

Introduction

Human well-being depends on protecting and preserving the functioning of oceans and coastal ecosystems. Over three billion people rely on these incredibly biodiverse ecosystems for their livelihoods, and even more depend on the services healthy ocean and coastal ecosystems provide, including food, storm surge protection, and cultural resources. Healthy marine ecosystems are essential for maintaining life on Earth; however, the ocean faces unprecedented anthropogenic threats, reducing its ability to provide crucial benefits to humans and other species that depend on 53 it.

To achieve global sustainability and effective ocean stewardship, the international community has pledged to conserve global marine ecosystems, notably through the United Nations Convention on Biological Diversity (CBD) and the United Nations 2030 Agenda for Sustainable Development (2030 Agenda). In 2010, in Nagoya, Japan, the Parties to the CBD adopted the Strategic Plan for Biodiversity 2011-2020 (Strategic Plan). The Strategic Plan is an overarching framework of 20 aspirational benchmarks - termed the "Aichi Biodiversity Targets"- that countries and stakeholders should meet in order to safeguard biodiversity by 2020. In 2015 UN Member States

61 adopted the Sustainable Development Goals (SDGs) which set the direction for achieving global 
63 Biodiversity Targets and Goal 14, which focuses on the need to conserve the ocean and its 64 resources, is of particular relevance to marine conservation efforts.

65 In the mid-term assessment of progress towards the implementation of the Strategic Plan, the 66 fourth edition of the Global Biodiversity Outlook (GBO-4, Secretariat of the CBD, 2014) 67 concluded that although good progress had been made in some areas, it was unlikely that many of 68 the Aichi Biodiversity Targets would be reached by 2020. The report on SDG 14 progress (UN, 69 2017) underlined that existing policies and treaties are still insufficient to combat the adverse 70 effects of climate change, overexploitation of resources, and pollution.

71 With 2020 on the horizon, the $4^{\text {th }}$ World Conference on Marine Biodiversity (WCMB) in 2018 in 72 Montreal, Canada, implemented a mentoring program to bring together early career researchers 73 with more senior scientists in working groups during the conference to synthesize the 74 achievements of a decade of work on 'Strategies for conservation of marine biodiversity'. One of 75 the working groups focused on critically evaluating the role of conservation paradigms and 76 technology in achieving the Aichi Biodiversity Targets. While recognizing that many targets 77 overlap and that all 20 targets are linked to marine conservation, the group identified the most relevant targets to four core themes of marine conservation: restoration (Aichi target 15), 79 protection (Aichi target 11), monitoring (Aichi target 19), and sustainable use (Aichi target 6) 80 (Table 1). In this review paper, the group discusses both the accomplishments towards and 81 shortfalls of achieving these four targets and suggests priorities for marine biodiversity 82 conservation to be considered in the post-2020 Global Biodiversity Framework ("post-2020 83 Framework").

84 As the CBD contracting parties continue discussing how to meet the 2050 Vision for Biodiversity 85 (CBD, 2020), numerous resulting assessments stress the need to build off the past decade's 86 achievements by critically evaluating implementation of the Strategic Plan and demonstrating 87 concrete examples of success. Consultation groups also emphasize need for including input from 88 diverse perspectives, including youth, in the post-2020 Framework (CBD, 2019a; CBD, 2019b). 89 Our synthesis of progress made towards Aichi targets 6, 11, 15, and 19, and respective future 90 priorities, can serve as guidance for future CBD Working Group discussions. 


\section{Review}

93 Aichi target 6 - By 2020 all fish and invertebrate stocks and aquatic plants are managed and harvested sustainably, legally and applying ecosystem based approaches, so that overfishing is avoided, recovery plans and measures are in place for all depleted species, fisheries have no significant adverse impacts on threatened species and vulnerable ecosystems and the impacts of fisheries on stocks, species and ecosystems are within safe ecological limits.

There have been some successes over the last decade against Aichi target 6 .

The number of stocks fished within biologically sustainable levels has increased in the Northeast Atlantic, Australia, and broadly across the Pacific. However, the general trend for global fisheries remains negative as the percentage of stocks fished at biologically unsustainable levels increases (FAO, 2018). Challenges to achieving sustainable fisheries include insufficient data, habitat loss, and a disconnect between humans and the environment (Hazen et al., 2016). Spatial constraints and jurisdictional boundaries can also pose challenges to taking ecosystem-based management $(\mathrm{EBM})$ approaches to fisheries and requires spatial management units that recognize both local ecological and socio-economic benefits (Sanchirico \& Wilen, 2005; Kenny et al., 2018). Implementing a holistic ecosystem-based approach to management is complex, especially because views vary on the fundamental principles of such an approach (Long, Charles and Stephenson, 2015).

111 Different considerations for developing versus developed countries can also make governance

112 challenging; for example engaging multiple stakeholders, adopting decentralized governance

113 strategies, and achieving long term sustainability through EBM approaches can be easier in

114 wealthy developed countries with greater resources (Gutierrez, Hilborn \& Defeo, 2011; DuBois

115 \& Zografos, 2012; Cinner et al., 2016; Kenny et al., 2018; Teh et al., 2018). In addition, fishing

116 access agreements with wealthy countries permitting the harvesting of demersal and highly

117 migratory species within the Exclusive Economic Zones (EEZ) of developing countries (Gagern

118 \& van den Bergh, 2013) can create a challenge for sustainable fisheries within these developing

119 countries' waters.

120 At the local level, sustainable management of smaller artisanal fisheries can be realized through

121 place-based strategies and an increased awareness of socio-economic and cultural benefits such

122 as enhanced food security (Kittinger et al., 2015; Stuart et al., 2019 Communities with strong 
123 cultural connections to coastal resources are, however often data limited and lack resources for

124 combating the knowledge gap in applying market-based approaches and industrial supply chains

125 to small-scale fisheries (Smith, 2008; O’Rourke, 2014; Kittinger et al., 2015).

126 Although many preventative actions have been implemented at various scales to address

127 overfishing and depleted stocks (European Union, 2008; Papaioannou, 2016; FAO, 2018; Oozeki

128 et al., 2018; Satria, 2018), illegal, unreported, and unregulated (IUU) fishing remains a threat

129 globally for marine conservation efforts. Improved technological, enforcement, and/or

130 compliance measures are needed to tackle this challenge across and beyond national

131 jurisdictions.

132 While some regional fish stocks have shown recovery (OSPAR, 2017; van Gemert \& Andersen,

133 2018) through improved management, many are still in decline. Climate change poses a growing

134 challenge to developing and implementing recovery plans in addition to predicting optimum

135 sustainable yield (Vert-pre et al., 2013; Britten et al., 2017; Teh et al., 2018). As ocean

136 temperatures continue to rise, low latitude or warm-water species are projected to migrate

137 poleward (Jones \& Cheung, 2015; Morley et al., 2018) leading to increased catch at higher

138 latitudes and decreased catch in lower latitudes (Cheung et al., 2013, Cheung et al., 2016;

139 Blanchard et al., 2012). Changes in marine fish stock distribution occur on local and regional

140 scales, with decreasing harvests predicted in the tropics and regions nutritionally and

141 economically dependent on fisheries (Bell et al., 2016; Barange et al., 2014). For all fisheries,

142 EBM, including science-based recovery plans, stakeholder agreements, and human behavioral

143 change, are critical for sustainable harvesting of fish, shellfish and aquatic plants within safe

144 ecological limits for future generations.

145 Greater success in meeting the aims of Aichi Target 6 can be achieved through identifying

146 priority areas of focus and attainable outcomes for sustainable, EBM using long-term adaptive

147 approaches (Teh et al., 2018) which consider climate change. For instance, recent reviews on

148 shark and ray conservation have illustrated the knowledge gap in the coupled dynamics of human

149 dimensions (e.g., socio-economic status, political stakeholders, market demands, enforcement

150 capacity) and natural population drivers (e.g., life history traits, habitat availability) (Gaymer et

151 al., 2014; Dent \& Clarke, 2015; Jaiteh et al., 2017; Martin et al., 2016; Martins et al., 2018),

152 which could be targeted as a priority area for research. Adaptive conservation solutions and

153 policies should be adopted in the face of global disparities, such as governance, resource

Peer) reviewing PDF | (2019:07:39530:2:0:NEW 21 Jul 2020) 
154 dependence, and monitoring and enforcement capacity (Lucifora et al., 2019; Mizrahi et al., 155 2019) that often stifle progress.

156 The post-2020 Framework should consider a few priority areas. Recovery plans and avoidance of

157 overfishing of stocks should focus on flexible solutions at different scales that target knowledge

158 gaps and the address the challenges posed by the highly mobile, transboundary nature of many

159 fish stocks. The negative impacts environmental impacts of fishing needs to continue to be

160 addressed with a focus on adverse impacts on vulnerable ecosystems and threatened species,

161 along with IUU. Cross-boundary, governmental, and institutional sharing of data and best

162 management practices should be improved to help develop a more transparent, adaptive,

163 resilient, and robust framework for sustainable EBM fishing practices.

164 Effective implementation of recovery plans and ending overexploitation of current stocks require

165 a greater understanding of the parallel components of species life history and gear-related

166 mortality. Life history traits often explain demographic characteristics that drive stock dynamics,

167 such as size at maturity, age of recruitment, and maximum sustainable yield. These

168 characteristics are even more important in data-poor habitats such as the deep sea, where

169 organisms are slow growing, long living, and often have lower reproduction potential, making

170 these ecosystems highly vulnerable to overfishing (Koslow, 1997; FAO, 2009). Long-term,

171 flexible management planning for highly vulnerable ecosystems should therefore include

172 realistic timespans to distinguish natural fluctuations in population dynamics from impacts of

173 overfishing (Clark et al., 2016). Incorporating knowledge of fish physiology, spatial behavior of

174 stocks, gear interactions, and economic values into stock assessments at the global scale can also

175 improve recovery efforts (Lynch et al., 2012; Poloczanska et al., 2013; Lagasse et al., 2015;

176 Horodysky et al., 2016). Managers should therefore develop flexible and adaptive recovery plans

177 that incorporate information on life history traits and population dynamics, measures for

178 stochastic biological and environmental events (Pershing et al., 2015; Britten et al., 2017), as

179 well as strategic spatial plans for monitoring and enforcement (Costa et al., 2018). Implementing

180 these strategies will allow policy makers to address changes in global fisheries as a result of

181 climate-driven stressors. Target-based spatial planning software such as Marxan (Ball et al.,

182 2009) or Zonation (Moilanen, 2007) can facilitate an adaptative framework, allowing resource

183 managers to use an array of biological information along with fishing effort data to improve

184 time-space management approaches in addition to addressing economic and political insecurities 
185 for developing nations (e.g. Kathijotes, 2013) or nations at risk from climate-induced stressors

186 (e.g. Mercer et al., 2012; Mamauag et al., 2013).

187 Current efforts to reduce negative fisheries impacts on a global scale include approaches such as

188 bycatch reduction strategies (Swimmer et al., 2011; O’Neill \& Mutch, 2017; Veiga-Malta et al., 189 2018), bans on harvests of certain species (Sherman et al., 2018), elimination of discards

190 (European Union, 2013), regulating exports related to non-sustainable fisheries (Shiffman \&

191 Hueter, 2017), fishing regulatory closures for Vulnerable Marine Ecosystems (VME) in Areas

192 Beyond National Jurisdiction (ABNJ) (NEAFC, 2018), prohibition of destructive gear types for

193 VMEs (Auster et al., 2011), marine protected areas (Hameed et al. 2017; Hastings et al. 2017),

194 and increased aquaculture production (FAO 2018; Froehlich et al. 2017). Implementation of

195 conservation measures such as large-scale marine protected areas can pose challenges for nations

196 that close off areas of their waters; however cross-jurisdictional management with transferable

197 fishing rights has been proposed as a potentially viable market-based solution to promote

198 transboundary cooperation in these situations (Villaseñor-Derbez et al. 2020). Major concern

199 remains, however, for sustainable management of fish stocks in ABNJ (Cullis-Suzuki \& Pauly,

200 2010) and about the impacts of fishing activities to deep-sea ecosystems (Koslow et al., 2000;

201 FAO 2008; Brock et al., 2009; Ramirez-Llodra et al., 2011), as well as IUU fishing in polar areas

202 (Ainley \& Pauly, 2014; Österblom et al., 2014; Nyman, 2018).

203 Understanding adverse impacts from overfishing should include historical, present, and projected

204 priority areas to inform better implementation of global ecosystem-based practices. Future

205 practices for regions that have multiple fisheries and/or rely on potentially harmful gear types

206 (e.g. bottom trawls, bottom longline) (Clark \& Koslow, 2008; Halpern et al., 2007) should be

207 critically evaluated at an ecosystem level. As deep-sea fisheries become more prevalent because

208 of recent advances in gear technology, precautionary measures should be put in place to assess

209 damage and recovery potential. Long term impacts of gear interactions in the deep sea can have

210 delayed responses reflected in a degraded seabed environment and remaining fauna (Clark et al.,

211 2010; Williams et al., 2010). A feedback mechanism for management that includes historical

212 data and periodically updated models or rapid assessments would provide a process for extensive

213 review and integration of new information.

214 The sharing of management outcomes, information on species life history across regions (e.g.,

215 ontogenetic shifts, foraging behaviour), and guidelines and best practices across boundaries 
216 (disciplinary, political, governmental, institutional, sectoral) could be improved through the use

217 of information sharing frameworks. For example, regional guidelines and approved practices for

218 global issues such as invasive species and highly migratory fish stocks have been successful in

219 coordinating common language and strategies across political and regional boundaries

220 (Lascelles, 2014; Morris, 2012; Serdy, 2016). Governance of fish stocks between communities at

221 local scales would also benefit from sharing resources (e.g., biological sampling, analytical

222 modeling), use of traditional ecological knowledge, and active engagement of the public

223 (Tallman et al. 2019). Open communication and flexible solutions may allow for better decision-

224 making and cooperation among stakeholders that differ in socio-economic status. Cross-

225 boundary, governmental, and institutional sharing of best management practices will also

226 enhance the capacity to holistically evaluate the efficacy of current recovery plans and fisheries

227 mitigation impacts. The use of a more robust, collaborative framework, inclusive of climate

228 change impacts, population drivers, and socio-economic information across regions will aid in

229 assessing how to achieve sustainable harvest of fish stocks within safe ecological limits for all

230 marine fauna and their living environment.

231

232

Aichi target 11 - By 2020, at least 17 per cent of terrestrial and inland water, and 10 per

233 cent of coastal and marine areas, especially areas of particular importance for biodiversity and ecosystem services, are conserved through effectively and equitably managed, ecologically representative and well-connected systems of protected areas and other effective area-based conservation measures, and integrated into the wider landscape and seascapes.

238 As a target obligating Contracting Parties to meet measurable commitments by 2020 (Campbell 239 et al., 2014), and as the most intensively studied of the Aichi targets (Green et al., 2019), Target

24011 should have proven a relatively easy target to assess in terms of achievements for marine conservation and associated future priorities. However, work towards this target to date appears to have had complex, and sometimes conflicting, outcomes. For instance, progress towards areabased protection seems to have resulted in less attention being paid to the management, representativeness, broader integration, and connectivity of conservation measures (i.e., qualitative measures), which are also specified components of Target 11. 
246 Progress towards the quantitative part of the target - for 10\% of coastal and marine areas to be

247 protected (Convention on Biological Diversity, 2011) - has been much slower than progress

248 towards the terrestrial equivalent, which aims for protection of at least $17 \%$ of inland areas

249 (Watson et al., 2014). The total ocean area covered by marine protected areas (MPAs) increased

250 from 2.3\% in 2011 (Leadley et al., 2014) to 7.91\% in 2020 (UNEP-WCMC and IUCN, 2020a).

251 However, protected area coverage is uneven, with most MPAs restricted to national waters,

252 covering around $18.45 \%$ of exclusive economic zones (EEZ), and only $1.18 \%$ of Areas Beyond

253 National Jurisdiction (ABNJ; UNEP-WCMC and IUCN, 2020a). To be ecologically

254 representative, MPAs need to protect the full range of habitats found within our ocean, both

255 nearshore and away from the coast. There is also socioeconomic disparity in achieving this

256 target. For instance, while $40 \%$ of high-income countries already exceed the $10 \%$ minimum for

257 protected national marine surface area, $75 \%$ of the waters of developing nations protect less than

$2582 \%$ (Failler et al., 2019). Further work still needs to be undertaken to understand the contribution

259 that other effective area-based conservation measures could make to the achievement of the

260 target (IUCN WCPA, 2018).

261 Furthermore, it has been argued that a recent focus on area-based measures of progress towards

262 Aichi targets has not resulted in the protection of a diverse range of habitats (Fischer et al., 2019)

263 nor of the most threatened areas (Kuempel et al., 2019). For instance, despite the contributions of

264 ABNJ to marine biodiversity and ocean health (Barbier et al., 2014), and the relatively higher

265 vulnerability of life in this area (O'Hara et al., 2019), high seas habitats remain underrepresented

266 in current protected areas. Steps have been made towards conserving deep-sea ecosystems via

267 various protected-area-oriented policies and projects (Calado et al., 2011; DFO, 2017; OSPAR

268 Commission, 2017), but most of the active hydrothermal vent environments that have been

269 protected to date fall within country jurisdictions across the globe (Menini and Van Dover, 2019;

270 Van Dover et al., 2012) and spreading ridges are particularly underrepresented in MPAs globally

271 (Fischer et al., 2019).

272 The recent acceleration towards the establishment of very large MPAs (Boonzaier and Pauly

273 2016), such as the Ross Sea Protected Area and the Papahānaumokuākea Marine National

274 Monument, has resulted in a rapid increase in percentage of global oceans within MPAs. An

275 analysis in 2014 found that ten MPAs (existing or under creation) accounted for more than 53\%

276 of the world's total MPA coverage in 2014 (Devillers et al., 2015; Watson et al., 2014); since 
277 then many others have been created (MCI, 2020). Therefore, without these large MPAs, the $10 \%$

278 target would be even further from being reached. Moreover, MPAs within Large Marine

279 Ecosystems do not represent the majority of geomorphic features and habitats found within them

280 (Fischer et al., 2019).

281 Although some progress is being made towards the quantitative element of the target, it is widely

282 recognized that further work is required on its qualitative components (Campbell \& Gray, 2019;

283 Green et al., 2019; Lemieux et al., 2019). Carr et al. (2017) elaborate on the importance of

284 various types of ecological spatial connectivity - population, genetic, community, and

285 ecosystem - that refer to the movement of genes, individuals, species, nutrients, and materials

286 between areas. Considering biodiversity representation and connectivity within MPA networks

287 can enhance biodiversity persistence and efficiency of conservation (Magris et al., 2018). Thus,

288 design and implementation strategies have changed from designating single, unrepresentative

289 MPAs to establishing large and inclusive MPAs and important networks of MPAs, such as on the

290 California coast and in the Northeast Atlantic (OSPAR, 2006; CDFW, 2016). Despite increasing

291 efforts to create MPA networks and improve ecological connectivity, few MPAs (11\% of 746

292 MPAs) explicitly mentioned connectivity as an ecological criterion as of 2019 (Balbar \&

293 Metaxas, 2019). In particular, there is a real paucity of research on larval ecology and dispersal

294 in VMEs, such as deep-sea habitats (Hilário et al., 2015), where species are strongly adapted to

295 specific conditions. For example, chemosynthetic habitats are so distinct that so-called 'stepping-

296 stone environments' might be far apart from one another, limiting connectivity among distant

297 MPAs and requiring protection spanning large 'metacommunities' (Mullineaux et al., 2018;

298 Suzuki et al., 2018). While the importance of connectivity in conservation planning strategies is

299 still under debate (Costello and Connor, 2019), this concept should still be considered in MPA

300 planning for all ecosystems, especially in cases over longer distances (Manel, Loiseau, and

301 Puebla, 2019) and should increasingly use genetic data sources (Xuereb et al., 2019; Zeng et al.,

302 2019).

303 Information on MPA management measures is lacking globally, and the effectiveness of these

304 measures at maintaining or restoring biodiversity is still under great debate (EEA, 2015;

305 MedPAN \& UNEP-MAP-SPA/RAC, 2016; Rees et al., 2018; Sala et al., 2018; Campbell \&

306 Gray, 2019). Currently only 1\% (UNEP-WCMC and IUCN, 2020b) to $4.8 \%$ of global MPAs are

307 considered fully implemented and managed (MCI, 2020). The rest of the designated MPAs either 
308 have not implemented or evaluated existing management strategies (UNEP-WCMC and IUCN, 309 2020b) or still allow significant extractive activities (Giakoumi et al. 2017). For coral reefs, 47\%

310 of MPAs were ineffective, 38\% partially effective, and only $15 \%$ fully effective (Burke et al.,

311 2011). In this case, the lack of effectiveness was a result of the management framework being

312 ignored or not enforced; insufficiently addressing threats within borders of MPAs via regulation;

313 and the location of MPAs failing to address real threats to reefs (Burke et al., 2011). Meanwhile,

314 Lyme Bay MPA in the UK provides a contrasting example of the benefits of addressing

315 qualitative measures, where involving stakeholders in conservation decisions facilitated

316 ecological recovery and improvements to equity amongst different fishing groups (Johnson et al.,

317 2019). This is also done within the MPA network in California, where a commitment to

318 monitoring, coordination, public education, and enforcement, along with strong public and

319 stakeholder engagement, has led to demonstrated success (Murray and Hee, 2019). Overall,

320 beyond size, these studies emphasize how the equitable management of MPAs shapes

321 conservation effectiveness.

322 The qualitative components of Target 11 are also affected by complex socio-economic and 323 environmental trade-offs (Zafra-Calvo et al., 2019). On larger scales, the implementation of

324 coastal or large MPAs in developed and developing countries is hampered by economic forces,

325 (e.g., Amengual and Alvarez-Berastegui, 2018; Driscoll et al., 2018), which can lead to instances

326 where the government proposes the removal of protections, for example against mining (Pinheiro

327 et al., 2019). In high-income countries of the Mediterranean, most long-term MPA monitoring

328 programs have been carried out with the support of research projects and were only occasionally

329 financed by the MPA management body (Rilov et al., 2019). By contrast, in developing

330 countries, economic development remains the main public policy concern, which is insufficiently

331 geared towards environmental protection (World Bank, 2017). Thus, we suggest that a future

332 research priority should involve the investigation of the values humans place on different aspects

333 of biodiversity and ecosystem functioning, as well as improved communication on the benefits

334 provided by MPAs, as there have been cases illustrating the potential improvements to MPA

335 effectiveness facilitated by incorporating social outcomes in MPA design (MacKeracher et al.,

336 2018; Folkersen et al., 2019).

337 Looking to the future, we propose that experiences, data, and guidelines should be shared across

338 political boundaries. Technological advancements and accumulated baseline data should improve 
339 identification of ecosystems in critical need of protection, while international communication

340 among managers and researchers can facilitate global information exchange, leading to the early

341 identification and protection of at-risk ecosystems. Building a platform for this knowledge

342 exchange should be a key priority of the post-2020 Framework and could build on existing data-

343 sharing platforms (such as Ocean Biogeographic Information System (www.obis.org) or Global

344 Biodiversity Information Facility (www,gbif.org), and will be necessary to prevent confusing

345 contradictions (e.g., see Gownaris et al., 2019) and to ensure conservation strategies can be

346 effective in both national and international waters, across a variety of habitats.

347 The effective implementation of conservation strategies is a crucial part of achieving

348 conservation success. Proper implementation requires identifying the most effective conservation

349 strategies, optimizing regulations to promote sustainable use of marine resources, involving local

350 dependent communities, and using more efficient and effective monitoring and enforcement

351 methods (Lemieux et al., 2019). Identifying the best methods for each component will require

352 collaboration among multiple stakeholders, as well as the appropriate resources to implement

353 these strategies, which has proved challenging thus far. Since the ocean is an interconnected and

354 dynamic system, there is a critical need to ensure effective management of all ocean areas and

355 uses. Thus, we propose that less well-known areas, such as deep-sea ecosystems and ecosystems

356 in countries with limited financial and technological capacity, should be prioritized for data

357 collection and capacity-building within the post-2020 Framework, as comprehensive datasets are

358 required to minimize bias in protected-area representation (Roberts et al., 2019). This will

359 require collaboration between scientists, managers, civil associations, and policymakers (Juniper

360 et al., 2019). Novel approaches for more efficient data collection, dissemination, and re-use

361 should also be an urgent priority (Edgar et al., 2016), as well as the incorporation of volunteer-

362 contributed data and local and traditional knowledge into conservation decision making. New

363 metrics may be required to incorporate data from such a variety of sources and to assess the

364 effectiveness of conservation measures (e.g. see Jantke et al., 2018 and McQuatters-Gollop et al., 365 2019).

366 Finally, even within effectively managed MPAs, another great challenge remains for marine

367 conservation - climate change (Bruno et al., 2018). Already, elevated temperatures have led to

368 the collapse of coral reefs, which are some of the most biodiverse ecosystems in tropical regions

369 (Hughes et al., 2017b). Expanding our understanding of climate-driven changes to the ocean is a 
370 key priority to better comprehend and anticipate their impacts on marine biodiversity.

371 Appropriate baseline data is fundamental to this, and past and present data must be used to model

372 future scenarios (Nicholson et al., 2019). Incorporation of these data and models into coastal and

373 ocean planning is essential (Legg and Nagy, 2006; Nicholson et al., 2019) within MPA network

374 design guidelines (Munguia-Vega et al., 2018), or in protection and restoration plans for habitats

375 vital for carbon sequestration and storage. Protection from anthropogenic stressors through

376 MPAs may improve the resilience of fauna ahead of climate change impacts (e.g., see Bates et

377 al., 2014). Species sensitive to ocean warming, however, are not guaranteed protection even by

378 the most effectively managed MPA. For example, due to the warming of coastal waters, sea

379 urchin populations have totally disappeared from a marine reserve in the southeastern

380 Mediterranean that has been protected for more than two decades (Rilov, 2016). Additionally,

381 species ranges may change as a result of climate change impacts, moving populations outside of

382 MPA boundaries. As such, a flexible, adaptive approach needs to be taken that allows for

383 boundary modifications of MPAs in response to these changes.

384 Recent developments in discussions informing the post-2020 Framework have called for the 10\%

385 quantitative element of this target to increase to $30 \%$ (CBD, 2020). Whether we consider the

386 Aichi Target of $10 \%$, or the ambitious new 30\% target, the result is the same: we still have far to

387 go as a global community to ensure that protected areas adequately conserve the ocean and its

388 valuable resources.

389

390

Aichi target 15 - By 2020, ecosystem resilience and the contribution of biodiversity to

391 carbon stocks has been enhanced, through conservation and restoration, including

392 restoration of at least 15 per cent of degraded ecosystems, thereby contributing to climate

393 change mitigation and adaptation and to combating desertification.

394 Anthropogenic impacts have eroded the resilience of many ecosystems across the globe,

395 triggering significant declines and losses of many of them (UNEP 2006), resulting in a reduction

396 of the services they provide, and negatively impacting human well-being (IPBES 2018). In order

397 to improve ecosystem resilience, there is increasing interest in not just conservation but also

398 restoration. In this section, we review six highly valuable global marine and coastal habitats to

399 illustrate the services they provide (Table 2), their status, and the efforts to restore them. 
400 Coral reefs have declined worldwide, with 50\% of Great Barrier Reef corals dying in 2016 and 4012017 alone (Hughes et al, 2019). Reef restoration has been attempted via culturing of asexually 402 produced coral fragments and occasionally the rearing and settling of coral larvae (Guest et al., 403 2014); however, coral restoration is still in its infancy. Some small-scale successes have occurred 404 in recent years (e.g., Guest et al., 2014; Cruz \& Harrison, 2017); for example, a breeding 405 population of one coral species (i.e. Acropora tenuis) was re-established in three years by 406 deploying coral larvae into mesh enclosures in the reefs (Cruz \& Harrison, 2017).

407 Similarly, nearly $50 \%$ of the world's mangrove forests have disappeared since the 1960s (Giri et 408 al., 2011). Restoration attempts have been made, but at a smaller scale and success rate than 409 depletion has occurred (Romañach et al., 2018). For example, half of the 67 planting efforts in 410 Sri Lanka since 2004 showed no surviving plants; only 200-220 hectares have been successfully 411 restored (Kodikara et al., 2017).

412 Despite the fact that global declines of seaweed forests are small on average, significant declines 413 have been confirmed at the local scale in 38\% of ecoregions (Krumhansl et al., 2016). Although 414 seaweed restoration is gaining recognition (Gianni et al., 2013), there have only been a few long415 term (Verdura et al., 2018) and large-scale successful restoration projects (Campbell et al., 416 2014). Seagrass beds are also declining, and almost $28 \%$ of their global extent has been lost since 4171879 (Orth et al., 2006; Waycott, 2009). Since the 1970s, seagrass restoration trials have rapidly 418 increased worldwide (Paling et al., 2009; van Katwijk et al., 2016), but only a few successful 419 projects have been reported, mainly due to low performance rates and small-scale efforts of the 420 restoration actions (Bayraktarov et al., 2016; van Katwijk et al., 2016). Similarly, saltmarshes are 421 severely threatened; approximately $50 \%$ of salt marshes worldwide have been lost or degraded 422 due to environmental stress and human disturbances (Adam, 2002; Valiela et al., 2009). In 423 denuded areas, natural regeneration might be difficult (Laegdsgaard, 2002), and despite salt 424 marsh restoration's receiving more attention and having higher success rates than other marine 425 coastal habitats, large-scale restoration projects (of more than a few hectares) are still needed 426 (Bayraktarov et al., 2016).

427 Substantial historical and continued extraction of oysters via fishing has led to $>85 \%$ loss in 428 oyster reefs worldwide and declines in oysters due to overharvest have been exacerbated by 429 degraded water and habitat quality (Beck et al., 2011; Diggles, 2013; Peters et al, 2017). Several 430 small- and medium-scale restoration efforts have taken place in response to this decline with 
431 mixed success (Schulte et al., 2009; Powers et al., 2009; Beck et al., 2011; Puckett \& Eggleston, 432 2012; La Peyre et al., 2014; Hernandez et al., 2018); most of these restoration efforts were in the 433 US, even though oyster reefs occur in both temperate and tropical locations globally.

434 Aquaculture of native oyster species has also become a focus, providing oysters for harvest and 435 delivering additional ecosystem services like those provided via restoration, but the benefits and 436 extent to which aquaculture provides these additional ecosystem services has not yet been

437 thoroughly reviewed (Higgins et al., 2011; Alleway et al., 2019).

438 Restoring and managing these crucial habitats will continue to be a challenge (La Peyre et al., 439 2014), especially due to shifting baselines because of climate change (Lemasson et al., 2017; van 440 Oppen et al., 2017; Wood et al., 2019). Of the 62 countries assessed in 2016, only 50\% had set 441 national goals with clear alignment with Target 15, and fewer had set quantitative targets 442 (Secretariat of the Convention on Biological Diversity, 2019). Despite many countries taking 443 positive steps, efforts have not been enough to reach the $15 \%$ target and further development of 444 methods and techniques for successful restoration is essential for the post-2020 Framework. This 445 includes developing and using indicators of ecosystem degradation and restoration, such as water 446 quality, carbon stocks, fish stocks, and species diversity (Secretariat of the Convention on 447 Biological Diversity, 2019).

448 Generally, the failure of restoration plans is mainly linked to low survival rates $(<52 \%$ mean 449 survival during the first two years post restoration) and to the small scale (a few hectares or less) 450 that restoration plans normally span (Bayraktarov et al., 2016). Moreover, filling the knowledge 451 gaps that have limited restoration of these ecosystems on a global scale to date should be 452 prioritized. For instance, acquiring and synthesizing information on the historical and present 453 distribution, species-specific population demographics, habitat requirements (Bayraktarov et al., 454 2016; Hernandez et al., 2018; Puckett et al., 2018; Theuerkauf et al., 2019), and habitat pre455 degradation state (Secretariat of the Convention on Biological Diversity, 2019) will be essential. 456 Additionally, restoration success could be enhanced by better understanding how the spatially 457 explicit distribution and heterogeneity of habitats can affect the occurrence and strength of 458 between-species interactions, habitat connectivity, or favorable environmental conditions 459 (Boström et al., 2011). The establishment of systematic monitoring and habitat mapping 460 initiatives will be crucial in supporting restoration through the adoption of a seascape or context461 appropriate approach at multiple scales. 
462 Due to the important role the habitats discussed here can play in maintenance of biodiversity, 463 climate regulation, and climate change adaptation and mitigation, further efforts to restore these 464 habitats will be vital (IPCC 2019). To preserve marine biodiversity and promote ecosystem 465 resilience to mitigate or adapt to future threats, restoration should be linked to the increasing 466 understanding of the response of marine ecosystems to climate change and its interaction with 467 other stressors. In this context, we suggest that global information exchange of baseline data 468 together with technologically advanced tools (e.g., modeling) will be key for managers and

469

470

471

472

473

474

475

476

477

478

479

480

481

482

483

484

485

486

487

488

489

490

491

researchers to identify best practices for ecosystem restoration and conservation. This also includes understanding past and present data, the natural/unimpacted state of the ecosystem prior to perturbations, and responses of ecosystems to different threats based on experimental and observational data, and on modeling and prediction. Such knowledge will allow managers and researchers to identify the most suitable areas for restoration or conservation. Specific examples include areas with less severe predicted climate change scenarios; already affected areas where restoration could mitigate future threats; or areas of special interest, such as those harboring high local or regional diversity and/or valuable ecosystems.

\section{Aichi target 19 - By 2020, knowledge, the science base and technologies relating to} biodiversity, its values, functioning, status and trends, and the consequences of its loss, are improved, widely shared and transferred, and applied.

Scientific knowledge of biodiversity and ecosystem functioning has significantly increased in the past decade through increased capacity, implementation, and awareness of the benefits of monitoring at a higher spatial and temporal resolution. The development and increasingly widespread use of innovative technologies and informatics has allowed for non-invasive and low-cost methods for long-term, continuous measurements of biodiversity. These technologies include automated monitoring systems such as passive and active acoustic monitoring (Buscaino et al., 2016; McWilliam et al., 2017; Monczak et al., 2017; Egerton et al., 2018), autonomous underwater vehicles (Griffin et al., 2017; Ferrari et al., 2016; Ferrari et al., 2018), and highresolution models of critical habitats for biodiversity (e.g., Allen Coral Atlas https://allencoralatlas.org/, structure-from-motion and benthic imagery models) (Asaad et al., 2019; Friedman et al., 2012; Burns et al., 2015; Ismail et al., 2015; González-Rivero et al., 2017). 
493 The establishment of expansive monitoring network programs has enabled greater coverage for

494 biodiversity monitoring and a platform for data sharing among scientists at local (e.g., Long

495 Term Ecological Reserves (LTER Network, 2018)), regional (e.g., SponGES (SponGES, 2018)),

496 and even global scales (e.g., OBIS, GOOS (Global Ocean Observing System), MarineGEO

497 (https://marinegeo.si.edu/)) (Saeedi et al., 2019). The increasing use of citizen science, through

498 app-based programs such as SeagrassSpotter (https://seagrassspotter.org/) and iNaturalist

499 (https://www.inaturalist.org/), has also facilitated quick and widespread data collection and

500 processing, which are crucial for rapid biodiversity assessments (Dickinson et al., 2012; Marshall

501 et al., 2012; Zenetos et al., 2013). Long-term citizen science projects can also document

502 ecosystem change, which is especially important for data-poor regions with limited resources,

503 such as the coral reef systems in Indonesia (Gouraguine et al., 2019).

504 Despite dramatic increases in data collection over the past decade, these resources have yet to be

505 fully extended to and applied in marine biodiversity policy and management (Heck et al., 2012;

506 Petes et al., 2014). Translating data into conservation requires that data repositories contain high

507 quality and widely accessible biodiversity resources, which can inform implementation of EBM.

508 Additional research must be done to understand the effectiveness of big, unstructured datasets

509 associated with mass sampling and citizen science (Bayraktarov et al., 2019) to address

510 biodiversity questions.

511 Increased efforts to standardize the collection of relevant, targeted biological data (e.g., Essential

512 Ocean Variables and Essential Biological Variables), sampling methods, and paired

513 environmental and metadata has already enabled better data sharing among scientific groups and

514 between scientists and managers, which can promote more rapid and efficient legislative and

515 management action (De Pooter et al., 2017; Muller-Karger et al., 2018; Klein et al., 2019).

516 Protocols aimed at shifting current benefit-sharing and accessibility paradigms among

517 governments, stakeholders, and scientists would also ensure resource databases better serve

518 greater societal needs such as interdisciplinary knowledge exchange, scientific capacity-building,

519 and resource equity. Future guidelines should highlight the increased societal value of databases

520 that remove barriers to sharing and accessing resources (i.e., that are user-friendly and openly

521 accessible). Such guidelines could elicit use of indigenous knowledge and stakeholder

522 engagement, especially at a local scale, which are an important part of improved conservation

523 outcomes (for example, in MPA design) (Saarman et al., 2013; Burt et al., 2014). 
524 As technology continues to rapidly outpace policy reform, the post-2020 Framework must also

525 address protocols for handling emerging issues with data collection, sharing, and application.

526 Specific guidelines should address marine genetic resources and their impact on biodiversity and

527 conservation going forward. Such guidelines should thoroughly outline protocols for current and

528 future scientific and private-sector acquisition and distribution of genetic resources, including

529 how to address future technological advancements surrounding biodiversity genetics. Although

530 many nations are still developing policy around genetic resources — and/or participating in the

531 Nagoya Protocol on Access and Benefit Sharing - this international framework should

532 communicate benefits and responsibilities of resource sharing among stakeholders, governments,

533 and scientific communities (Harden-Davies and Gjerde, 2019). The biodiversity framework

534 should work in conjunction with policy resulting from early 2020 Nagoya Protocol meetings to

535 establish applicable and actionable guidelines for access and benefit sharing as it pertains to

536 marine biodiversity resources.

537 Incomplete application of science-informed policy means that despite advances in knowledge,

538 data, and technology, this target has only been partially achieved in the marine environment. The

539 post-2020 Framework should prioritise research on the efficiency of unstructured data, citizen

540 science, and other tools or strategies to inform implementation of EBM. Increasing societal

541 participation in and awareness of biodiversity conservation should also be prioritized, in order to

542 address outstanding knowledge gaps and contribute to an integrated solution for applying science

543 to marine policy and management (Hyder et al., 2015; Jarvis et al., 2015; Theobald et al., 2015).

544 Priority should also be given to developing a framework for cross-boundary resource and benefit

545 sharing as it relates to current biodiversity data and future resources arising from technology and

546 genetic data advancements. Prioritizing these three areas will maximize the impact and longevity

547 of guidelines going forward. Specifically, new legislation regarding biodiversity targets should

548 be created within an adaptive framework that relies on frequent reporting and review of existing

549 policy, both globally and within contracting party countries. This adaptive framework will

550 require discussion among multiple stakeholders and institutions that monitor biodiversity status

551 and will encourage cross-boundary cooperation among groups by holding them accountable for

552 reliable and up-to-date reporting. It will also provide opportunities for the incorporation of

553 emerging data and technologies into policy, and for flexibility of policy in response to unstable

554 conditions driven by climate change. Increased reliance on globally accessible databases and 
555 data management frameworks, such as OBIS, by scientists and managers will be required (Klein

556 et al., 2019). Clear metrics for policy evaluation should also be outlined to streamline efficient

557 reporting and review and encourage a common language across sectors. At the global level,

558 successful strategies for EBM should be shared to provide examples for regions struggling with

559 effective and sustainable management; at the local level, positive incentives should be created for

560 EBM to engage multiple stakeholders and partnerships among local communities and managers.

561 Incorporating a human-perspective approach will be key to addressing biodiversity challenges

562 related to applying science-informed policy moving forward. Mainstreaming biodiversity in

563 policy and the private sector will promote further sustainable development. Linking the post-

5642020 Framework to other societal challenges such as climate change, human health, and disaster

565 risk reduction, will better connect biodiversity to goals of other goals and commitments, in turn

566 strengthening the use of common language and information sharing across boundaries.

567 Mainstreaming biodiversity in communications and encouraging ocean literacy will help

568 individuals see value in nature and encourage involvement in nature-related decisions that may

569 directly affect them and their communities. One approach to this is incorporating a nature-based

570 curriculum in schools (e.g., Lawson et al., 2019). Clear communication of the benefits provided

571 by, and cost of inaction towards, biodiversity targets in terms of ecological, social, economic,

572 and political stability is necessary to increase societal awareness of these issues. Providing

573 tangible alternatives that integrate sustainable actions with social benefits will also be important

574 to encourage a shift in human behaviour. Governance systems should also be more transparent

575 and inclusive, which will build trust between local communities and government, and provide

576 opportunities for involvement by indigenous and local groups.

577

\section{Conclusion}

579 Although progress has been made towards achieving the goals of the Strategic Plan for

580 Biodiversity for the marine environment, the Aichi targets reviewed have not been fully

581 achieved. This substantiates the predictions of GBO-4 and is unsurprising given the aspirations

582 of the targets and the complexity of implementation. Ongoing discussions within CBD on the

583 development of the Zero Draft of the Post-2020 Global Biodiversity Framework will set out the

584 approach to address some of these shortfalls and provide continuing momentum towards the

5852050 vision. To deliver this vision, it is important that the new targets and actions that come out 
586 of this agreed framework are fostered and implemented at a range of scales, highlighting the key

587 need for stakeholder involvement, including local communities and youth. The UN Decade of

588 Ocean Science for Sustainable Development (2021-2030) ("the Decade") also provides a great

589 opportunity to build on existing foundations to better understand changes and reverse the

590 declines observed in our ocean. Climate change and the mainstreaming of biodiversity into

591 policy, the economy, and society will be major challenges for marine conservation strategies and

592 should set the context for conservation work, even — or especially — in the face of uncertainty.

593 The rising importance of the climate change agenda and increasing recognition within sectors

594 such as finance of the very real risk that impacts of climate change pose to the environment,

595 economy, and community stability, could lead to more governments proactively tackling this

596 issue. Implementing an adaptive approach to the post-2020 Framework that incorporates a range

597 of feedback mechanisms from multiple sectors, including youth and indigenous and local

598 communities, will be necessary to enhance marine conservation efforts while promoting

599 economic sustainability, as well as to support the resilience of coastal communities in the face of

600 climate change.

601 A common theme across the priorities identified here is the need for better recognition of global

602 economic disparities and calls for flexible solutions in the context of socio-economic trade-offs.

603 Critically addressing priorities to decrease overfishing, increase area-based protection, and

604 enhance enforcement capacity - especially in cross-boundary fisheries and critical habitats-will

605 require stakeholders to modify their perspectives on social or market-based incentives for

606 conservation. The value of marine biodiversity varies across regions, where some nations are

607 solely dependent on coastal waters for their citizens' livelihoods. Appropriate measures include

608 area-based management, restoration, and protection and fisheries recovery plans; current

609 international fisheries should also consider economic constraints in regions projected to be less

610 capable of tackling climate or other anthropogenic stressors. Future decision-making processes

611 should include bioeconomics to assess capacity and the feasibility of implementing conservation

612 strategies.

613 Another common theme is the need for improved sharing of data, information, and experiences

614 among scientists, stakeholders, the public, and policy makers and improving these connections.

615 Having sufficient baseline data and scientific understanding of marine ecosystems is essential for

616 successful conservation efforts; therefore, the collection of useful data using a range of 
617 mechanisms (including citizen science), and data in areas with less coverage is also paramount.

618 The knowledge and views of the public should be more readily and consistently considered in

619 management, and novel approaches for gaining this intelligence/human capital explored.

620 Collecting and synthesizing multiple data types using a systematic approach will be imperative.

621 Sharing of scientific, local, and traditional knowledge coupled with equitable funding

622 mechanisms will enable less developed countries lacking resources to implement conservation

623 measures in their waters. Better communication, sharing experiences, and exchanging knowledge

624 among groups, sectors, and nations will be key and should be fostered in part by encouraging

625 accountability across these different networks.

626 As discussions progress on the legally binding global treaty on the conservation and sustainable

627 use of $\mathrm{ABNJ}$, there is a huge potential for a significant win for marine biodiversity and humanity

628 alike. Coupled with the new 2050 Vision for Biodiversity; the Decade; the UNFCCC COP 26

629 and upcoming revisions to nations' nationally determined contributions to addressing climate

630 change; and the SDGs, this would offer a much brighter outlook for the future of marine

631 biodiversity.

632 With the stark challenges facing global biodiversity recently highlighted by experts with regards

633 to climate change (IPCC, 2019) and unprecedented biodiversity loss (IPBES, 2019) it is

634 imperative now more than ever that actions are taken to implement conservation strategies in the

635 most effective ways possible to optimize the chances of their success and of making a positive

636 impact on the health of our marine ecosystems. We hope that focusing efforts on the priorities set

637 out here at all scales and across all sectors will facilitate achieving this goal.

638

639 Acknowledgements

640 This research is sponsored by the NSERC Canadian Healthy Oceans Network (CHONe) and its

641 Partners: Department of Fisheries and Oceans Canada and INREST (representing the Port of

642 Sept-Îles and City of Sept-Îles). This paper is a collaboration resulting from a mentoring program

643 as part of the World Conference on Marine Biodiversity 2018 held in Montreal Canada. We

644 would like to thank the mentorship program organizing committee and workshop facilitators

645 David Beauchesne, Rémi M. Daigle, Jésica Goldsmit, Philippe Archambault, Anna Metaxas, and

646 Paul Snelgrove and would like to thank Lisa Mertens, Marie Pierrejean, Zahra Alsaffar, and the 
647 WCMB 2018 mentoring program participants for their contributions to the ideas underpinning 648 this paper.

649 


\section{References}

651 Adam P. 2002. Saltmarshes in a time of change. Environmental Conservation 29:39-61 DOI:

$65210.1017 / \mathrm{S} 03768929000048$.

653 Ainley DG, Pauly D. 2014. Fishing down the food web of the Antarctic continental shelf and

654 slope. Polar Record 50:92-107. DOI:10.1017/S0032247412000757.

655 Airoldi L, Beck MW .2007. Loss, status and trends for coastal marine habitats of Europe.

656 Oceanography and Marine Biology 45:345-405 DOI: 10.1201/9781420050943.ch7.

657 Alleway HK, Gillies CL, Bishop MJ, Gentry RR, Theuerkauf SJ, Jones R. 2019. The Ecosystem

658 Services of Marine Aquaculture: Valuing Benefits to People and Nature. BioScience 69. DOI:

659 10.1093/biosci/biy137.

660 Almada GVMB, Bernardino AF. 2017. Conservation of deep-sea ecosystems within offshore oil

661 fields on the Brazilian margin, SW Atlantic. Biological Conservation 206:92-101 DOI:

662 10.1016/j.biocon.2016.12.026.

663 Amengual J, Alvarez-Berastegui D. 2018. A critical evaluation of the Aichi Biodiversity Target

66411 and the Mediterranean MPA network, two years ahead of its deadline. Biological Conservation

665 225: 187-196 DOI: 10.1016/j.biocon.2018.06.032.

666 Ardron JA, Clark MR, Penney AJ, Hourigan TF, Rowden AA, Dunstan PK, Watling L, Shank

667 TM, Tracey DM, Dunn MR, Parker SJ. 2014. A systematic approach towards the identification

668 and protection of vulnerable marine ecosystems. Marine Policy 49:146-154 DOI:

669 10.1016/j.marpol.2013.11.017.

670 Asaad I, Lundquist CJ, Erdmann MV, Costello MJ. 2019. An interactive atlas for marine

671 biodiversity conservation in the Coral Triangle. Earth System. Sci. Data. 11, 163-174.

672 DOI: 10.5194/essd-11-163-2019.

673 Auster PJ, Gjerde K, Heupel E, Watling L, Grehan A, Rogers AD. 2011. Definition and

674 detection of vulnerable marine ecosystems on the high seas: problems with the 'moveon' rule.

675 ICES Journal of Marine Science 68:254-264 DOI: 10.1093/icesjms/fsq074.

676 Babb A. 2015. Industrial development within the Blue Economy: 'What these Ithacas mean'.

677 Development 58:587-593 DOI: 10.1057/s41301-016-0046-9.

678 Balbar, A and Metaxas, A. In press. 2019. The current application of ecological connectivity in

679 the design of marine protected areas. 
680 Ball IR, Possingham HP, Watts M. 2009. Marxan and relatives: software for spatial conservation 681 prioritisation. In Spatial Conservation Prioritization: Quantative Methods \& Computational 682 tools. Moilannen A, Wilson KA, Possingham (eds). Oxford University Press, United Kingdom. 683 pp.185-195.

684 Barange M, Merino G, Blanchard JL, Scholtens J, Harle J, Allison EH, Allen J, Holt J, Jennings 685 S. 2014. Impacts of climate change on marine ecosystem production in societies dependent on 686 fisheries. Nature Climate Change 4:211-216 DOI: 10.1038/nclimate2119.

687 Barbier EB, Hacker SD, Kennedy C, Koch EW, Stier AC, Silliman BR. 2011. The value of 688 estuarine and coastal ecosystem services. Ecological Monographs 81:169-193 DOI: 10.1890/106891510.1.

690 Barbier EB, Moreno-Mateos D, Rogers AD, Aronson J, Pendleton L, Danovaro R, Henry LA, 691 Morato T, Ardron J, Van Dover CL. 2014. Protect the deep sea. Nature 505:475-477 DOI: $69210.1038 / 505475 \mathrm{a}$.

693 Bates AE, Barrett NS, Stuart-Smith RD, Holbrook NJ, Thompson PA, Edgar GJ. 2014.

694 Resilience and signatures of tropicalization in protected reef fish communities. Nature Climate 695 Change 4:62-67. DOI: 10.1038/nclimate2062.

696 Bayraktarov E, Saunders MI, Abdullah S, Mills M, Beher J, Possingham HP, Mumby PJ, 697 Lovelock CE. 2016. The cost and feasibility of marine coastal restoration. Ecological 698 Applications 26:1055-1074 DOI: 10.1890/15-1077.

699 Bayraktarov, E; Ehmke, G; O'Connor, J; Burns, EL; Nguyen, HA; McRae, L; Possingham, HP. 700 2019. Do big unstructured biodiversity data mean more knowledge? Frontiers in Ecology and 701 the Environment, 6 , Article 239. DOI: 10.3389/fevo.2018.00239.

702 Beck MW, Brumbaugh RD, Airoldi L, Carranza A, Coen LD, Crawford C, Defeo O, Edgar GJ, 703 Hancock B, Kay MC, Lenihan HS, Luckenbach MW, Toropova CL, Zhang G, Guo X. 2011.

704 Oyster Reefs at Risk and Recommendations for Conservation, Restoration, and Management. 705 BioScience 61. DOI: 10.1525/bio.2011.61.2.5.

706 Bell JD, Cheung W, De Silva S, Gasalla M, Frusher S, Hobday A, Lam V, Lehodey P, Pecl G, 707 Samoilys M, Senina I. 2016. Chapter 4.5: Impacts and effects of ocean warming on the 708 contributions of fisheries and aquaculture to food security. In Explaining Ocean Warming:

709 Causes, scale, effects, and consequences. International Union for Conservation of Nature and

710 Natural Resources (IUCN). Laffoley D, Baxter JM (ed). Gland, Switerzerland. Pp.409-437. 
711 Bellwood DR, Hoey AS, Choat JH. 2003. Limited functional redundancy in high diversity

712 systems: resilience and ecosystem function on coral reefs. Ecology Letters 6:281-285. DOI:

713 10.1046/j.1461-0248.2003.00432.x.

714 Bennett NJ, Dearden P. 2014. Why local people do not support conservation: Community

715 perceptions of marine protected area livelihood impacts, governance and management in

716 Thailand. Marine Policy 44:107-116. DOI: 10.1016/j.marpol.2013.08.017.

717 Bennett N, Roth R, Klain S, Chan K, Christie P, Clark D, Cullman G, Curran D, Durbin T,

718 Epstein G, Greenberg A, Nelson M, Sandlos J, Stedman R, Teel T, Thomas R, Veríssimo D,

719 Wyborn C. 2017. Conservation social science: Understanding and integrating human

720 dimensions to improve conservation. Biological Conservation 205:93-108 DOI:

721 10.1016/j.biocon.2016.10.006.

722 Bird T, Bates A, Lefcheck J, Hill N, Thomson R, Edgar G, Stuart-Smith R, Wotherspoon S,

723 Krkosek M, Stuart-Smith J, Pecl G, Barrett N, Frusher S. 2014. Statistical solutions for error and

724 bias in global citizen science dataset. Biological Conservation 173:144-154. DOI:

725 10.1016/j.biocon.2013.07.037.

726 Blanchard JL, Jennings S, Holmes R, Harle J, Merino G, Allen JI, Holt J, Dulvy NK, Barange M.

727 2012. Potential consequences of climate change for primary production and fish production in

728 large marine ecosystems. Philosophical Transactions of the Royal Society B: Biological

729 Sciences, 367:1605. DOI:10.1098/rstb.2012.0231.

730 Boonzaier L, Pauly D. 2016. Marine protection targets: an updated assessment of global

731 progress. Oryx 50: 27-35 DOI: $\underline{10.1017 / \mathrm{S} 0030605315000848}$.

732 Boström C, Pittman S, Simenstad C, Kneib R. 2011. Seascape ecology of coastal biogenic

733 habitats: Advances, gaps, and challenges. Marine Ecology Progress Series 427:191-217 DOI:

734 10.3354/meps09051.

735 Britten GL, Dowd M, Kanary L, Worm B. 2017. Extended fisheries recovery timelines in a

736 changing environment. Nature Communications 8:15325 DOI: 10.1038/ncomms15325.

737 Brock R, English E, Kenchington E, Tasker M. 2009. The alphabet soup that protects cold-water

738 corals in the North Atlantic. Marine Ecology Progress Series 397:355-360 DOI:

$73910.3354 /$ meps08303. 
740 Bruno JF, Bates AE, Cacciapaglia C, Pike EP, Amstrup SC, van Hooidonk R, Henson SA,

741 Aronson RB. 2018. Climate change threatens the world's marine protected areas. Nature Climate

742 Change 8:499-503. DOI: 10.1038/s41558-018-0149-2.

743 Burke L, Reytar K, Spalding M, Perry A. 2011. Reefs at risk revisited. World Resources

744 Institute: Washington, DC. 115 pp.. http://www.vliz.be/en/imis?refid=223234 (accessed 5 March

745 2019).

746 Burns JHR, Delparte D, Gates RD, Takabayashi M. 2015. Integrating structure-from-motion

747 photogrammetry with geospatial software as a novel technique for quantifying 3D ecological

748 characteristics of coral reefs. PeerJ 3:e1077. DOI: 10.7717/peerj.1077.

749 Burt JM, Akins P, Latham E, Beck M, Salomon AK, Ban NC. 2014. Marine protected area

750 network design features that support resilient human-ocean systems - Applications for British

751 Columbia, Canada. Simon Fraser University:159. DOI: 10.13140/RG.2.2.26024.98564.

752 Buscaino G, Ceraulo M, Pieretti N, Corrias V, Farina A, Filiciotto F, Maccarrone V, Grammauta

753 R, Caruso F, Giuseppe A, Mazzola S. 2016. Temporal patterns in the soundscape of the shallow

754 waters of a Mediterranean marine protected area. Scientific Reports 6:34230. DOI:

755 10.1038/srep34230.

756 Calado, H, Ng K, Lopes C, Paramio L. 2011. Introducing a legal management instrument for

757 offshore marine protected areas in the Azores-The Azores Marine Park. Environmental science

758 \& policy 14(8):1175-1187. DOI: 10.1016/j.envsci.2011.09.001.

759 Cameron E, Yuckin S, Bayne E. 2013. Communicating research with the public: evaluation of an

760 invasive earthworm education program. NeoBiota 19:83-97 DOI: 10.3897/neobiota.19.4848.

761 Campbell AH, Marzinelli EM, Vergés A, Coleman MA, Steinberg PD. 2014. Towards

762 restoration of missing underwater forests. PLoS One 9(1): e84106 DOI:

763 10.1371/journal.pone.0084106.

764 Campbell LM, \& Gray N J. 2019. Area expansion versus effective and equitable management in

765 international marine protected areas goals and targets. Marine Policy, 100(March), 192-199.

766 DOI: 10.1016/j.marpol.2018.11.030.

767 Carr, MH, Robinson, SP, Wahle, C, Davis G, Kroll S, Murray S, Schumacker EJ, Williams M.

768 2017. The central importance of ecological spatial connectivity to effective coastal marine

769 protected areas and to meeting the challenges of climate change in the marine environment. 
770 Aquatic Conservation: Marine and Freshwater Ecosystems. 27( S1): 6- 29. DOI:

771 10.1002/aqc.2800.

772 CBD. 2019a. Report of the regional consultation workshop on the post-2020 global biodiversity

773 framework for Asia and the Pacific, Nagoya, Japan, 28-31 January 2019. Available at:

774 https://www.cbd.int/doc/c/4a6a/21b1/882c0bd47225fd46b320a650/post2020-ws-2019-01-02-

775 en.pdf.

776 CBD. 2019b. Report of the regional consultation on the post-2020 global biodiversity framework

777 for Latin America and the Caribbean, Montevideo, 14-17 May 2019. Available at:

778 https://www.cbd.int/doc/c/02cb/463a/68d6d12ff6a3c200cebc0240/post2020-ws-2019-05-02-

779 en.pdf.

780 CBD Open Ended Working Group on the post-2020 global biodiversity framework. 2020. Zero

781 draft of the post-2020 global biodiversity framework - note by the co-chairs. CBD/WG2020/2/3.

782 Available at: cbd/wg2020/2/3 (accessed 22 January 2020).

783 CBD Subsidiary Body on Scientific, Technical and Technological Advice. 2018. Updated

784 scientific assessment of progress towards selected Aichi Biodiversity Targets and options to

785 accelerate progress - Note by the Executive Secretary. CBD/SBSTTA/22/INF/10. Available at:

786 https://www.cbd.int/doc/c/6db8/2029/d3de020ab5b7b039e9d665dd/sbstta-22-inf-10-en.pdf

787 (accessed 11th April 2019).

788 CDFW (California Department of Fish and Wildlife). 2016. California Marine Life Protection

789 Act Master Plan for Marine Protected Areas. Adopted by the California Fish and Game

790 Commission on August 24, 2016. Available at

791 www.wildlife.ca.gov/Conservation/Marine/MPAs/Master-Plan (accessed 23 July 2018).

792 Cheung WW, Watson R, Pauly D. 2013. Signature of ocean warming in global fisheries catch.

793 Nature 497:365-368. DOI: 10.1038/nature12156.

794 Cheung WWL, Jones MC, Reygondeau G, Lam VWY. 2016. Structural uncertainty in projecting

795 global fisheries catches under climate change. Ecological Modelling 325:57-66. DOI:

796 10.1016/j.ecolmodel.2015.12.018.

797 Chmura GL, Anisfeld SC, Cahoon DR, Lynch JC. 2003. Global carbon sequestration in tidal,

798 saline wetland soils. Global Biogeochemical Cycles 1:1111 DOI: 10.1029/2002GB001917.

799 Cinner JE, Huchery C, MacNeil MA, Graham NAJ, McClanahan TR, Maina J, Maire E,

800 Kittinger JN, Hicks CC, Mora C. Allison EH, D'Agata S, Hoey A, Feary DA, Crowder L, 
801 Williams ID, Kulbicki M, Vigliola L, Wantiez L, Edgar G, Stuart-Smith RD, Sandin SA, Green 802 AL, Hardt MJ, Beger M, Friedlander A, Campbell SJ, Holmes KE, Wilson SK, Brokovich E, 803 Brooks AJ, Cruz-Motta JJ, Booth DJ, Chabanet P, Gough C, Tupper M, Ferse SC, Sumaila UR, 804 Mouillot D. 2016. Bright spots among the world's coral reefs. Nature 535 (7612):416-419 DOI: $80510.1038 /$ nature18607.

806 Clark MR, Koslow JA. 2008. Impacts of fisheries on seamounts. In Seamounts:Ecology,

807 Fisheries and Conservation. Pitcher TJ, MoratoT, Hart PJB, Clark MR, Haggan N, Santos RS 808 (eds).pp. 413-441. DOI: 10.1002/9780470691953.

809 Clark MR, Bowden DA, Baird SJ, Stewart R. 2010. Effects of fishing on the benthic biodiversity 810 of seamounts of the "Graveyard" complex, northern Chatham Rise. New Zealand Aquatic 811 Environment \& Biodiversity Report 46:1-6.

812 Clark MR, Althaus F, Schlacher TA, Williams A, Bowden AD, Rowden AA. 2016. The impacts 813 of deep-sea fisheries on benthic communities: A review. ICES Journal of Marine Science 73:i51814 i69. DOI:10.1093/icesjms/fsv123.

815 Convention on Biological Diversity. 2011. COP 10 Decision X/2: Strategic Plan for Biodiversity 816 2011-2020 http://www.cbd.int/decision/cop/?id=12268.

817 Costa MD, Mills M, Richardson AJ, Fuller RA, Muelbert JH, Possingham HP. 2018. Efficiently 818 enforcing artisanal fisheries to protect estuarine biodiversity. Ecological Applications 28:14508191458 DOI: $10.1002 /$ eap.1744.

820 Costanza R, D’Arge R, De Groot R, Farber S, Grasso M, Hannon B, Limburg K, Naeem S, 821 O’Neil R, Paruelo J, Raskin R, Sutton P, Van Den Belt M. 1997. The value of the world's 822 ecosystem services and natural capital. Nature 387:253-260. DOI: 10.1038/387253a0.

823 Costello MJ, Connor DW. 2019. Connectivity Is Generally Not Important for Marine Reserve 824 Planning. Trends in Ecology \& Evolution 34(8):686-688. DOI: 10.1016/j.tree.2019.04.015.

825 Cruz DWD, Harrison PL. 2017. Enhanced larval supply and recruitment can replenish reef corals 826 on degraded reefs. Scientific Reports 7:1-13 DOI: 10.1038/s41598-017-14546-y.

827 Cullis-Suzuki S \& Pauly D. 2010. Failing the high seas: a global evaluation of regional fisheries 828 management organizations. Marine Policy 34:1036-1042 DOI: 10.1016/j.marpol.2010.03.002.

829 Dabbadie L, Stankus A. 2017. Aquaculture in small island developing states. FAO Aquaculture 830 Newsletter 57:46-47. 
831 David G, Leopold M, Dumans PS, Ferraris J, Herrenschmidt JB, Fontenelle F. 2010. Integrated 832 coastal zone management perspectives to ensure the sustainability of coral reefs in New

833 Caledonia. Marine Pollution Bulletin 61:323-334. DOI: 10.1016/j.marpolbul.2010.06.020.

834 Dayton PK. 1985. Ecology of Kelp Communities. Annual Review of Ecology and Systematics $835 \quad 16: 215-245$

836 De Pooter D, Appeltans W, Bailly N, Bristol S, Deneudt K, Eliezer M, Fujioka E, Giorgetti A, 837 Goldstein P, Lewis M, Lipizer M, Mackay K, Marin M, Moncoiffé G, Nikolopoulou S, Provoost 838 P, Rauch S, Roubicek A, Torres C, van de Putte A, Vandepitte L, Vanhoorne B, Vinci M, 839 Wambiji N, Watts D, Klein Salas E, Hernandez F. 2017. Toward a new data standard for 840 combined marine biological and environmental datasets - expanding OBIS beyond species 841 occurrences. Biodiversity Data Journal. 5: e10989. DOI: 10.3897/BDJ.5.e10989.

842 Dean AJ, Church EK, Loder J, Fielding KS, Wilson KA. 2018. How do marine and coastal 843 citizen science experiences foster environmental engagement? Journal of Environmental 844 Management 213:409-416 DOI: 10.1016/j.jenvman.2018.02.080.

845 Dent F \& Clarke S. 2015. State of the global market for shark products. In: FAO Fisheries \& 846 Aquaculture Technical Paper 1:590. pp.187. Available at http://www.fao.org/3/a-i4795e.pdf.

847 Devillers R, Pressey RL, Grech A, Kittinger JN, Edgar GJ, Ward T, Watson R. 2015. Reinventing 848 residual reserves in the sea: are we favouring ease of establishment over need for 849 protection?. Aquatic conservation: marine and freshwater ecosystems 25: 480-504 DOI: $850 \quad 10.1002 /$ aqc. 2445.

851 Driscoll DA, Bland LM, Bryan BA, Newsome TM, Nicholson E, Ritchie EG, Doherty TS. 2018. 852 A biodiversity-crisis hierarchy to evaluate and refine conservation indicators. Nature ecology \& 853 evolution 2: 775-781 DOI: 10.1038/s41559-018-0504-8.

854 Devictor V, Whittaker R, Beltrame C. 2010. Beyond scarcity: citizen science programmes as 855 useful tools for conservation biogeography. Diversity and Distributions 16:354-362. DOI: 856 10.1111/j.1472-4642.2009.00615.x.

857 DFO. 2017. Fisheries and Oceans Canada, Government of Canada identifies large ocean area off 858 the coast of British Columbia for protection (News Release). Available at

859 https://www.canada.ca/en/fisheries-

860 oceans/news/2017/05/government_of_canadaidentifieslargeoceanareaoffthecoastofbritish.html 861 (accessed 24 July 2018). 
862 Dickinson J, Crain R, Yalowitz S, Cheery T. 2013. How Framing Climate Change Influences

863 Citizen Scientists' Intentions to Do Something About It. The Journal of Environmental

864 Education 44:145-158 DOI: 10.1080/00958964.2012.742032.

865 Dickinson JL, Shirk J, Bonter D, Bonney R, Crain RL, Martin J, Phillips T, Purcell K. 2012. The 866 current state of citizen science as a tool for ecological research and public engagement. Frontiers 867 in Ecology and the Environment 10:291-297 DOI: 10.1890/110236.

868 Diggles BK. 2013. Historical epidemiology indicates water quality decline drives loss of oyster 869 (Saccostrea glomerate) reefs in Moreton Bay, Australia. New Zealand Journal of Marine and 870 Freshwater Research 47: 561-581. DOI: 10.1080/00288330.2013.781511

871 Dinerstein E, Vynne C, Sala E, Joshi AR, Fernando S, Lovejoy TE, Mayorga J, Olson D, Asner 872 GP, Baillie JEM, Burgess ND, Burkart K, Noss RF, Zhang YP, Baccini A, Birch T, Hahn N, 873 Joppa LN, Wikramanayake E. 2019. The Global Deal for Nature sets an ambitious agenda to 874 protect our biosphere through ecosystem conservation and land restoration. Science Advances 875 5(4). DOI: 10.1126/sciadv.aaw2869.

876 Drake K, Halifax H, Adamowicz SC, Craft C. 2015. Carbon sequestration in tidal salt marshes of 877 the Northeast United States. Environmental management, 56 (4), 998-1008.

878 Drew JA. 2005. Use of traditional ecological knowledge in marine conservation. Conservation 879 Biology 19:1286-1293 DOI: 10.1111/j.1523-1739.2005.00158.x.

880 Druel E, Gjerde KM. 2014. Sustaining marine life beyond boundaries: Options for an

881 implementing agreement for marine biodiversity beyond national jurisdiction under the United

882 Nations Convention on the Law of the Sea. Marine Policy 49:90-97 DOI:

883 10.1016/j.marpol.2013.11.023.

884 Duarte CM, Chiscano CL. 1999. Seagrass biomass and production: a reassessment. Aquatic 885 Botany 65:159-174 DOI: 101016/S0304-3770(99)00038-8.

886 Duarte CM, Middelburg JJ, Caraco N. 2005. Major role of marine vegetation on the oceanic 887 carbon cycle. Biogeosciences 1:659-679 DOI: 10.5194/bg-2-1-2005.

888 DuBois C, Zografos C. 2012. Conflicts at sea between artisanal and industrial fishers: inter889 sectoral interactions and dispute resolution in Senegal. Marine Policy 36:1211-1220 DOI: 890 10.1016/j.marpol.2012.03.007. 
891 Edgar GJ, Bates AE, Bird TJ, Jones AH, Kininmonth S, Stuart-Smith RD, and Webb TJ. 2016.

892 New Approaches to Marine Conservation Through Scaling Up of Ecological Data. Annual

893 Review of Marine Science 8:435-61 DOI: 10.1146/annurev-marine-122414-033921.

894 EEA. 2015. Marine protected areas in Europe's seas - An overview and perspectives for the

895 future. EEA Report, no 3/2015 DOI: 10.2800/99473

896 Egerton JP, Johnson AF, Turner J, LeVay L, Mascareñas-Osorio I, Aburto-Oropeza O. 2018.

897 Hydroacoustics as a tool to examine the effects of Marine Protected Areas and habitat type on

898 marine fish communities. Scientific Reports 8 DOI: 10.1038/s41598-017-18353-3.

899 Elmgren R. 2001. Understanding human impact on the Baltic ecosystem: changing views in

900 recent decades. Ambio 30:222-231 DOI:10.1579/0044-7447-30.4.222.

901 European Union Council Regulation 1005/2008 and Commission Regulation (EC) No

902 1010/2009. Available at: https://eur-lex.europa.eu/legal-

903 content/EN/TXT/?qid=1408984470270\&uri=CELEX:02008R1005-20110309 and https://eur-

904 lex.europa.eu/legal-content/EN/TXT/?qid=1408984782181\&uri=CELEX:02009R1010-

$905 \underline{20130917}$ (accessed 23 August 2018).

906 European Union Council Regulation 1380/2013. Available at: https://eur-

907 lex.europa.eu/LexUriServ/LexUriServ.do?uri=OJ:L:2013:354:0022:0061:EN:PDF (accessed 23

908 August 2018).

909 Failler P, Touron-Gardic G, Traore M-S. 2019. Is Aichi Target 11 Progress Correctly Measured

910 for Developing Countries? Trends in Ecology \& Evolution 34(10):875-879. DOI:

911 10.1016/j.tree.2019.07.007.

912 FAO. 2008. Technical consultation on international guidelines for the management of deep-sea

913 fisheries in the high sea. Rome, 4-8 February 2008. TC: DSF/2008/Inf 3:33.

914 FAO. 2009. Management of Deep-Sea Fisheries in the High Seas. FAO Rome Italy. Available at

915 http://www.fao.org/3/i1064e/i1064e00.pdf.

916 FAO. 2018. The State of World Fisheries and Aquaculture 2018 - Meeting the sustainable

917 development goals. Rome. Licence: CC BY-NC-SA 3.0 IGO. Available at:

918 http://www.fao.org/documents/card/en/c/I9540EN/

919 Fariñas-Franco JM, Pearce B, Mair JM, Harries DB, MacPherson RC, Porter JS, Reimer PJ,

920 Sanderson WG. 2018. Missing native oyster (Ostrea edulis L.) beds in a European Marine

921 Protected Area: Should there be widespread restorative management? Biological Conservation 
922 221: 293-311. DOI: 10.1016/j.biocon.2018.03.010.

923 Ferrari R, Marzinelli EM, Ayroza CR, Jordan A, Figueira WF, Byrne M, Malcolm HA, Williams

924 SB., Steinberg PD. 2018. Large-scale assessment of benthic communities across multiple marine

925 protected areas using an autonomous underwater vehicle. PLOS ONE 13:e0193711 DOI:

926 10.1371/journal.pone.0193711.

927 Ferrari R, McKinnon D, He H, Smith R, Corke P, González-Rivero M, Mumby P, Upcroft B.

928 2016. Quantifying Multiscale Habitat Structural Complexity: A Cost-Effective Framework for

929 Underwater 3D Modelling. Remote Sensing 8:113 DOI: 10.3390/rs8020113.

930 Ferrario F, Beck M, Storlazzi C, Micheli F, Shepard C, Airoldi L. 2014. The effectiveness of

931 coral reefs for coastal hazard risk reduction and adaptation. Nature Communications 5:3794

932 DOI: $10.1038 /$ ncomms4794.

933 Ferse SCA, Costa MM, Máñez KS, Adhuri DS, Glaser M. 2010. Allies, not aliens: increasing the

934 role of local communities in marine protected area implementation. Environmental Conservation

935 37:23-34 DOI: 10.1017/S0376892910000172.

936 Fischer A, Bhakta D, Macmillan-Lawler M, Harris P. 2019. Existing global marine protected

937 area network is not representative or comprehensive measured against seafloor geomorphic

938 features and benthic habitats. Ocean \& Coastal Management 167:176-187. DOI:

939 10.1016/j.ocecoaman.2018.10.001.

940 Fisher R, O’Leary RA, Low-Choy S, Mengersen K, Knowlton N, Brainard RE, Caley MJ. 2015.

941 Species richness of coral reefs and the pursuit of convergent global estimates. Current Biology

942 25:500-505 DOI: 10.1016/j.cub.2014.12.022.

943 Folkersen MV, Fleming CM, Hasan S. 2019. Depths and uncertainty for deep-sea policy and

944 legislation. Global Environmental Change 54:1-5. DOI: 10.1016/j.gloenvcha.2018.11.002.

945 Fonseca MS, Cahalan JA. 1992. A preliminary evaluation of wave attenuation by four species of

946 seagrass. Estuarine, Coastal and Shelf Science 35:565-576 DOI: 10.106/S0272-7714(05)80039-

9473.

948 Fourqurean JW, Duarte CM, Kennedy H, Marbà, N, Holmer M, Mateo MA, Apostolaki ET,

949 Kendrick GA, Krause-Jensen D, McGlathery KJ, Serrano O. 2012. Seagrass ecosystems as a

950 globally significant carbon stock. Nature Geoscience 5:505-509 DOI: 10.1038/ngeo1477.

951 Friedman A, Pizarro O, Williams SB, Johnson-Roberson M. 2012. Multi-Scale Measures of

952 Rugosity, Slope and Aspect from Benthic Stereo Image Reconstructions. PLoS ONE 7 DOI: 
953 10.1371/journal.pone.0050440.Froehlich HE, Gentry RR, Halpern BS. 2017. Conservation

954 aquaculture: Shifting the narrative and paradigm of aquaculture's role in resource management.

955 Biological Conservation 215: 162-168. DOI:10.1016/j.biocon.2017.09.012.

956 Gagern A, van den Bergh. 2013. A critical review of fishing agreements with tropical developing 957 countries. Marine Policy 38:375-386 DOI: 10.1016/j.marpol.2012.06.016.

958 Ganase A, Hoegh-Guldberg O. 2017. Linking fishes to multiple metrics of coral reef structural 959 complexity using three-dimensional technology. Science Reports 7:13965 DOI: 10.1038/s41598$960 \quad 017-14272-5$

961 Garmendia E, Gamboa G, Franco J, Garmendia JM, Liria P, Olazabal M. 2010. Social multi-

962 criteria evaluation as a decision support tool for integrated coastal zone management. Ocean and 963 Coastal Management 53: 385-403 DOI: 10.1016/j.ocecoaman.2010.05.001.

964 Gaymer CF, Stadel AV, Ban NC, Cárcamo PF, Ierna J, Lieberknecht LM. 2014. Merging top965 down and bottom-up approaches in marine protected areas planning: experiences from around 966 the globe. Aquatic Conservation: Marine \& Freshwater Ecosystems 24:128-144.

967 DOI:10.1002/aqc.2508.

968 Giakoumi S, Scianna C, Plass-Johnson J, Micheli F, Grorud-Colvert K, Thiriet P, Claudet J, Di

969 Carlo G, Di Franco A, Gaines SD. 2017. Ecological effects of full and partial protection in the

970 crowded Mediterranean Sea: a regional meta-analysis. Scientific Reports 7:8940.

971 Gianni F, Bartolini F, Airoldi L, Ballesteros E, Francour P, Guidetti P, Meinesz A, Thibaut T,

972 Mangialajo L. 2013. Conservation and restoration of marine forests in the Mediterranean Sea and

973 the potential role of Marine Protected Areas. Advances in Oceanography and Limnology, 4:2,

974 83-101. DOI: 10.1080/19475721.2013.845604.

975 Gilby BL, Olds AD, Peterson CH, Connoly RM, Voss CM, Bishop MJ, Elliott M, Grabowski $976 \mathrm{JH}$, Ortodossi NL, Schlacher TA. 2018. Maximizing the benefits of oyster reef restoration for 977 finfish and their fisheries. Fish and Fisheries 19:931-947. DOI: 10.1111/faf.12301Gjerde KM, 978 Reeve LLN, Harden-Davies H, Ardron J, Dolan R, Durussel C, Earle S, Jimenez JA, Kalas P, 979 Laffoley D, Oral N, Page R, Ribeiro MC, Rochette J, Spadone A, Thiele T, Thomas HL, Wagner 980 D, Warner R, Wilhelm A, Wright G. 2016. Protecting Earth's last conservation frontier:

981 scientific, management and legal priorities for MPAs beyond national boundaries. Aquatic

982 Conservation: Marine and Freshwater Ecosystems 26:45-60 DOI: 10.1002/aqc.2646.

983 Giri C, Ochieng E, Tieszen LL, Zhu Z, Singh A, Loveland T, Masek J, Duke N. 2011. Status and 
984 distribution of mangrove forests of the world using earth observation satellite data. Global

985 Ecology and Biogeography 20:154-159 DOI: 10.1111/j.1466-8238.2010.00584.x.

986 Golléty C, Migné A, Davoult D. 2008. Benthic metabolism on a sheltered rocky shore: role of

987 the canopy in the carbon budget. Journal of Phycology 44:1146-1153 DOI: 10.1111/J.1529-

988 8817.2008.00569.x.

989 González-Rivero M, Harborne AR, Herrera-Reveles A, Bozec YM, Rogers A, Friedman A,

990 Grabowski JH, Brumbaugh RD, Conrad RF, Keeler AG, Opaluch JJ, Peterson CH, Piehler MF,

991 Powers SP, Smyth AR. 2012. Economic Valuation of Ecosystem Services Provided by Oyster

992 Reefs. BioScience 62: 900-909. DOI: 10.1525/bio.2012.62.10.10.

993 Gress SK, Huxham M, Kairo JG, Mugi LM, Briers RA. 2017. Evaluating, predicting and

994 mapping belowground carbon stores in Kenyan mangroves. Global Change Biology 23:224-234

995 DOI: $10.1111 / \mathrm{gcb} .13438$.

996 Gouraguine A, Moranta J, Ruiz-Frau A, Hinz H, Reñones O, Ferse SCA, Jompa J, Smith DJ.

997 2019. Citizen science in data and resource-limited areas: A tool to detect long-term ecosystem

998 changes. PLoS ONE, 14: e0210007. DOI: 10.1371/journal.pone.0210007.

999 Gownaris NJ, Santora CM, David JB, Pikitch EK. 2019. Gaps in Protection of Important Ocean

1000 Areas: A Spatial Meta-Analysis of Ten Global Mapping Initiatives. Frontiers in Marine Science

1001 6:650. DOI: 10.3389/fmars.2019.00650.

1002 Green EJ, Buchanan GM, Butchart SHM, Chandler GM, Burgess ND, Hill SLL, Gregory RD.

1003 2019. Relating characteristics of global biodiversity targets to reported progress. Conservation

1004 Biology 33(6):1360-1369. DOI: 10.1111/cobi.13322.

1005 Griffin KJ, Hedge LH, González-Rivero M, Hoegh-Guldberg OI, Johnston EL. 2017. An

1006 evaluation of semi-automated methods for collecting ecosystem-level data in temperate marine

1007 systems. Ecology and Evolution 7:4640-4650 DOI: 10.1002/ece3.3041.

1008 Grorud-Colvert K, Claudet J, Tissot BN, Caselle JE, Carr MH, Day JC, Friedlander AM, Lester

1009 SE, Lison de Loma T, Malone D, Walsh WJ. 2014. Marine Protected Area Networks: Assessing

1010 Whether the Whole Is Greater than the Sum of Its Parts. PLoS ONE 9(8): e102298 DOI:

1011 10.1371/journal.pone.0102298.

1012 Guest JR, Baria MV, Gomez ED, Heyward AJ, Edwards AJ. 2014. Closing the circle: is it

1013 feasible to rehabilitate reefs with sexually propagated corals? Coral Reefs 33:45-55 DOI:

1014 10.1007/s00338-013-1114-1. 
1015 Gutierrez NL, Hilborn R, Defeo O. 2011. Leadership, social capital and incentives promote

1016 successful fisheries. Nature 470:386-389 DOI: 10.1038/nature09689.

1017 Halpern BS, Selkoe KA, Micheli F, Kappel CV. 2007. Evaluating and ranking the vulnerability

1018 of global marine ecosystems to anthropogenic threats. Conservation Biology 21:1301-1315.

1019 Hameed SO, Cornick LA, Devillers R, Morgam LE. 2017. Incentivizing more effective marine

1020 protected areas with the Global Ocean Refuge System (GLORES). Frontiers in Marine Science

1021 4:208. DOI:10.3389/fmars.2017.00208.

1022 Harden-Davies HR, Gjerde KM. 2019. Building Scientific and Technological Capacity: A Role

1023 for Benefit-sharing in the Conservation and Sustainable Use of Marine Biodiversity beyond

1024 National Jurisdiction. Ocean Yearbook Online. 33:377-400. DOI: 10.1163/9789004395633_015.

1025 Hastings A Gaines S, Costello C. 2017. Marine reserves solve an important bycatch problem in

1026 fisheries. Proceedings of the National Academy of Sciences 114:8927-8934.

1027 DOI:10.1073/pnas.1705169114.

1028 Hazen L, Le Cornu E, Zerbe A, Martone R, Erickson AL, Crowder LB. 2016. Translating 1029 sustainable seafood frameworks to assess the implementation of ecosystem-based fisheries

1030 management. Fisheries Research 182:149-157 DOI: 10.1016/j.fishres.2015.11.019.

1031 Heck N, Dearden P, McDonald A. 2012. Insights into marine conservation efforts in temperate

1032 regions: Marine protected areas on Canada's West Coast. Ocean and Coastal Management

1033 57:10-20 DOI: 10.1016/j.ocecoaman.2011.11.008.

1034 Hernandez AB, Brumbaugh RD, Frederick P, Grizzle R, Luckenbach MW, Peterson CH,

1035 Angelini C. 2018. Restoring the eastern oyster: how much progress has been made in 53 years?

1036 Frontiers in Ecology and Environment 16:463-471. DOI: 10.1002/fee.1935.

1037 Heyward AJ, Smith LD, Rees M, Field SN. 2002. Enhancement of coral recruitment by in situ

1038 mass culture of coral larvae. Marine Ecology Progress Series 230:113-118 DOI:

$1039 \quad 10.3354 / \mathrm{meps} 230113$.

1040 Higgins CB, Stephenson K, Brown BL. 2011. Nutrient Bioassimilation Capacity of

1041 Aquacultured Oysters: Quantification of Ecosystem Service. Journal of Environmental Quality

1042 40:271-277. DOI: 10.2134/jeq2010.0203.

1043 Hilário A, Metaxas A, Gaudron SM, Howell KL, Mercier A, Mestre NC, Ross RE, Thurnherr

1044 AM, Young C. 2015. Estimating dispersal distance in the deep sea: challenges and applications

1045 to marine reserves. Frontiers in Marine Science 2:6 DOI: 10.3389/fmars.2015.00006. 
1046 Hill LS, Johnson JA, Adamowski J. 2016. Meeting Aichi Target 11: Equity considerations in

1047 Marine Protected Areas design. Ocean and Coastal Management 134:112-119 DOI:

1048 10.1016/j.ocecoaman.2016.09.017.

1049 Hockings M, Stolton S, Leverington F, Dudley N, Courrau J. 2006. Evaluating Effectiveness: A

1050 framework for assessing management effectiveness of protected areas. 2nd edition. IUCN,

1051 Gland, Switzerland and Cambridge, UK. xiv + 105 pp. Available at

$1052 \mathrm{https} / / / \mathrm{www} \cdot$ protectedplanet.net/c/protected-areas-management-effectiveness-pame (accessed 26

1053 August 2018).

1054 Horodysky AZ, Cooke SJ, Graves JE, Brill RW. 2016. Fisheries conservation on the high seas:

1055 linking conservation physiology and fisheries ecology for the management of large pelagic

1056 fishes. Conservation Physiology 4:cov059 DOI: 10.1093/conphys/cov059.

1057 Hughes TP, Kerry J, Álvarez-Noriega M, Álvarez-Romero J, Anderson K, Baird A, Babcock R,

1058 Beger M, Bellwood D, Berkelmans R, Bridge T, Butler I, Byrne M, Cantin N, Comeau S,

1059 Connolly S, Cumming G, Dalton S, Diaz-Pulido G, Eakin CM, Figueira W, Gilmour J, Harrison

1060 H, Heron S, Hoey AS, Hobbs JP, Hoogenboom M, Kennedy E, Kuo CY, Lough J, Lowe R, Liu

1061 G, Malcolm McCulloch HM, McWilliam M, Pandolfi J, Pears R, Pratchett M, Schoepf V,

1062 Simpson T, Skirving W, Sommer B, Torda G, Wachenfeld D, Willis B, Wilson S, 2017b. Global

1063 warming and recurrent mass bleaching of corals Nature 543: 373-377 DOI:

1064 10.1038/nature21707.

1065 Hughes TP, Kerry JT, Connolly SR, Baird AH, Eakin CM, Heron SF, Hoey AS, Hoogenboom

1066 MO, Jacobson M, Liu G, Pratchett MS, Skirving W, Torda G. 2019. Ecological memory

1067 modifies the cumulative impact of recurrent climate extremes. Nature Climate Change 9:40-43.

1068 DOI: $10.1038 / \mathrm{s} 41558-018-0351-2$.

1069 Hyder K, Townhill B, Anderson LG, Delany J, Pinnegar JK. 2015. Can citizen science contribute

1070 to the evidence-base that underpins marine policy? Marine Policy 59:112-120 DOI:

1071 10.1016/j.marpol.2015.04.022.

1072 IPBES. 2018. The IPBES assessment report on land degradation and restoration. Montanarella,

1073 L., Scholes, R., and Brainich, A. (eds.). Secretariat of the Intergovernmental Science-Policy

1074 Platform on Biodiversity and Ecosystem Services, Bonn, Germany. 744 pages.

1075 IPBES. 2019. Summary for Policymakers of the global assessment report on biodiversity and

1076 ecosystem services of the Intergovernmental Science-Policy Platform on Biodiversity and 
1077 Ecosystem Services - Advance Unedited Version 6 May 2019. Available at:

$1078 \mathrm{https}: / /$ www.dropbox.com/sh/yd812v0u4jqptp3/AAACtf6ctsoUQ9hlPQxLpVsKa?dl=0 (accessed

1079 8th May 2019).

1080 IPCC. 2018. Summary for Policymakers. In: Global Warming of $1.5^{\circ} \mathrm{C}$. An IPCC Special Report

1081 on the impacts of global warming of $1.5^{\circ} \mathrm{C}$ above pre-industrial levels and related global

1082 greenhouse gas emission pathways, in the context of strengthening the global response to the

1083 threat of climate change, sustainable development, and efforts to eradicate poverty [Masson-

1084 Delmotte, V., P. Zhai, H.-O. Pörtner, D. Roberts, J. Skea, P.R. Shukla, A. Pirani, W. Moufouma-

1085 Okia, C. Péan, R. Pidcock, S. Connors, J.B.R. Matthews, Y. Chen, X. Zhou, M.I. Gomis, E.

1086 Lonnoy, T. Maycock, M. Tignor, and T. Waterfield (eds.)]. World Meteorological Organization,

1087 Geneva, Switzerland, 32 pp. Available at:

$1088 \mathrm{https}: / / \mathrm{www} . i p c c . c h / s i t e / a s s e t s / u p l o a d s /$ sites/2/2018/07/SR15_SPM_version_stand_alone_LR.pd

$1089 \mathrm{f}$ (accessed 8th May 2019).

1090 Ismail K, Huvenne VAI, Masson DG. 2015. Objective automated classification technique for

1091 marine landscape mapping in submarine canyons. Marine Geology 362:17-32 DOI:

1092 10.1016/j.margeo.2015.01.006.

1093 IUCN WCPA. 2018. Applying IUCN's Global Conservation Standards to Marine Protected

1094 Areas (MPA). Delivering effective conservation action through MPAs, to secure ocean health \&

1095 sustainable development. Version 1.0. Gland, Switzerland. 4pp.

1096 Iveša L., Djakovac, T. and M. Devescovi. 2016. Long-term fluctuations in Cystoseira

1097 populations along the west Istrian Coast (Croatia) related to eutrophication patterns in the

1098 northern Adriatic Sea. Mar. Pollut. Bull. 106: 162-173.

1099 Jaiteh VF, Loneragan NR, Warren C. 2017. The end of shark finning? Impacts of declining

1100 catches and fin demand on coastal community livelihoods. Marine Policy 82:224-233.

1101 DOI:10.1016/j.marpol.2017.03.027.

1102 Jantke K, Kuempel CD, McGowan J, Chauvenet ALM, Possingham HP. 2018. Metrics for

1103 evaluating representation target achievement in protected area networks. Diversity and

1104 Distributions 25(2):170-175. DOI: 10.1111/ddi.12853.

1105 Jarvis RM, Breen BB, Krägeloh CU, Billington DR. 2015. Citizen science and the power of

1106 public participation in marine spatial planning. Marine Policy, 57:21-26 DOI:

1107 10.1016/j.marpol.2015.03.011. 
1108 Johnson DE, Rees SE, Diz D, Jones PJS, Roberts C, Froján CB. 2019. Securing effective and

1109 equitable coverage of marine protected areas: The UK's progress towards achieving Convention

1110 on Biological Diversity commitments and lessons learned for the way forward. Aquatic

1111 Conservation: Marine and Freshwater Ecosystems 29(S2):181-194.

1112 Jones MC, Cheung WWL. 2015. Multi-model ensemble projections of climate change effects on

1113 global marine biodiversity. ICES Journal of Marine Science 72:741-752 DOI:

1114 10.1093/iceasjms/fsu172.

1115 Juniper SK, Thornborough K, Douglas K, Hillier J. 2019. Remote monitoring of a deep-sea

1116 marine protected area: The Endeavour Hydrothermal Vents. Aquatic Conservation: Marine and

1117 Freshwater Ecosystems 29(S2):84-102. DOI: 10.1002/aqc.3020.

1118 Kathijotes N. 2013. Keynote: Blue economy-environmental and behavioral aspects towards

1119 sustainable coastal development. Procedia-Social \& Behavioral Sciences 101:7-13 DOI:

$1120 \quad$ 10.1016/j.sbspro.2013.07.173.

1121 Kellogg ML, Smyth AR, Luckenbach MW, Carmichael RH, Brown BL, Cornwell JC, Piehler

1122 MF, Owens MS, Dalrymple DJ, Higgins CB. 2014. Use of oysters to mitigate eutrophication in

1123 coastal waters. Estuarine, Coastal and Shelf Science 151. DOI: 10.1016/j.ecss.2014.09.025.

1124 Kenny AJ, Campbell N, Koen-Alonso M, Pepin P, Diz D. 2018. Delivering sustainable fisheries

1125 through adoption of a risk-based framework as part of an ecosystem approach to fisheries

1126 management. Marine Policy 93:232-240 DOI: 10.1016/j.marpol.2017.05.018.

1127 Kimirei IA, Nagelkerken I, Mgaya YD, Huijbers CM. 2013. The mangrove nursery paradigm

1128 revisited: Otolith stable isotopes support nursery-to-reef movements by Indo-Pacific fishes.

1129 PlosONE 8:e66320 DOI: 10.1371/journal.pone.0066320.

1130 Kittinger JN, Teneva LT, Koike H, Stamoulis KA, Kittinger DS, Oleson KLL, Conklin E,

1131 Gomes M, Wilcox B, Friedlander M. 2015. From reef to table: social and ecological factors

1132 affecting coral reef fisheries, artisanal seafood supply chains, and seafood security. PLoS ONE

1133 10:e0123856. DOI: 10.1371/journal.pone.0123856.

1134 Klein E, Appeltans W, Provoost P, Saeedi H, Benson A, Bajona L, Peralta AC and Bristol RS.

1135 2019. OBIS Infrastructure, Lessons Learned, and Vision for the Future. Frontiers in Marine

1136 Science. 6:588. DOI: 10.3389/fmars.2019.00588. 
1137 Kodikara KAS, Mukherjee N, Jayatissa LP, Dahdouh-Guebas F, Koedam N. 2017. Have

1138 mangrove restoration projects worked? An in-depth study in Sri Lanka. Restoration Ecology 25:

1139 705-716 DOI:10.1111/rec.12492.

1140 Koslow JA. 1997. Seamounts and ecology of deep-sea fisheries: The firm-bodied fishes that feed

1141 around seamounts are biologically distinct from their deepwater neighbors and may be especially

1142 vulnerable to overfishing. American Scientist 85:168-176. Available at:

1143 https://www.jstor.org/stable/27856735.

1144 Koslow JA, Boehlert GW, Gordon JDM, Haedrich RL, Lorance P, Parin N. 2000. Continental

1145 slope and deep-sea fisheries: implications for a fragile ecosystem. ICES Journal of Marine

1146 Science 57:548-557 DOI: 10.1006/jmsc.2000.0722.

1147 Krause-Jensen D, Duarte CM. 2016. Substantial role of macroalgae in marine carbon

1148 sequestration. Nature Geoscience 9:737-742 DOI: 10.1038/ngeo2790.

1149 Krumhansl KA, Okamoto DK, Rassweiler A, Novak M, Bolton JJ, Cavanaugh KC, Micheli F.

1150 2016. Global patterns of kelp forest change over the past half-century. Proceedings of the

1151 National Academy of Sciences 113:13785-13790 DOI: 10.1073/pnas.1606102113.

1152 Kuempel CD, Jones KR, Watson JEM, Possingham HP. 2019. Quantifying biases in marine-

1153 protected-area placement relative to abatable threats. Conservation Biology 33(6):1350-1359.

1154 DOI: $10.1111 /$ cobi.13340.

1155 Laegdsgaard P. 2002. Recovery of small denuded patches of the dominant NSW coastal

1156 saltmarsh species (Sporobolus virginicus and Sarcocornia quinqueflora) and implications for

1157 restoration using donor sites. Ecological Management and Restoration 3:200-204 DOI:

1158 10.1046/j.1442-8903.2002.00113.x.

1159 La Peyre MK, Nix A, Laborde L, Piazza BP. 2012. Gauging state-level and user group views of

1160 oyster reef restoration activities in the northern Gulf of Mexico. Ocean \& Coastal Management

1161 67:1-8. DOI: 10.1016/j.ocecoaman.2012.06.001.

1162 La Peyre MK, Humphries AT, Casas SM, La Peyre JF. 2014. Temporal variation in development

1163 of ecosystem services from oyster reef restoration. Ecological Engineering 63. DOI:

1164 10.1016/j.ecoleng.2013.12.001.

1165 La Peyre MK, Serra K, Joyner TA, Humphries A. 2015. Assessing shoreline exposure and oyster

1166 habitat suitability maximizes potential success for sustainable shoreline protection using oyster

1167 reefs. PeerJ DOI: 10.7717/peerj.1317. 
1168 Lagasse CR, Knudby A, Curtis J, Finney JL, Cox SP. 2015. Spatial analyses reveal conservation

1169 benefits for cold-water corals and sponges from small changes in a trawl fishery footprint.

1170 Marine Ecology Progress Series 528:161-172 DOI: 10.3354/meps11271.

1171 Lascelles B, Di Sciara GN, Agardy T, Cuttelod A, Eckert S, Glowka L, Hoyt E, Llewellyn F,

1172 Louzao M, Ridoux V, Tetley MJ. 2014. Migratory marine species: their status, threats and

1173 conservation management needs. Aquatic Conservation: Marine \& Freshwater Ecosystems

1174 24:111-127 DOI: 10.1002/aqc.2512.

1175 Lawson, DF, Stevenson, KT, Peterson, MN, Carrier SJ, Strnad RL, Seekamp E. 2019. Children

1176 can foster climate change concern among their parents. Nature Climate Change 9, 458-462.

1177 DOI:10.1038/s41558-019-0463-3.

1178 Leadley PW, Krug CB, Alkemade R, Pereira HM, Sumaila UR, Walpole M, Marques A,

1179 Newbold T, Teh LS, van Kolck J, Bellard C. 2014. Progress towards the Aichi Biodiversity

1180 Targets: An assessment of biodiversity trends, policy scenarios and key actions. Secretariat of

1181 the Convention on Biological Diversity (CBD) Technical Series (Vol. 78). Available at

1182 https://www.cbd.int/doc/publications/cbd-ts-78-en.pdf.

1183 Legg CJ, Nagy L. 2006. Why most conservation monitoring is, but need not be, a waste of time,

1184 Journal of Environmental Management 78(2), 194-199 DOI: 10.1016/j.jenvman.2005.04.016.

1185 Lemasson AJ, Fletcher S, Hall-Spencer JM, Knights AM. 2017. Linking the biological imipacts

1186 of ocean acidification on oyster to changes in ecosystem services: A review. Journal of

1187 Experimental Marine Biology and Ecology 492: 49-62. DOI: 10.1016/j.jembe.2017.01.019.

1188 Lemieux CJ, Gray PA, Devillers R, Wright PA, Dearden P, Halpenny EA, Groulx M, Beechey

1189 TJ, Beazley K. 2019. How the race to achieve Aichi Target 11 could jeopardize the effective

1190 conservation of biodiversity in Canada and beyond. Marine Policy 99:312-323. DOI:

1191 10.1016/j.marpol.2018.10.029.

1192 Lima Junior DP, Magalhães ALB, Pelicice FM, Vitule JRS, Azevedo-Santos VM, Orsi ML,

1193 Simberloff D, Agostinho AA. 2018. Aquaculture expansion in Brazilian freshwaters against the

1194 Aichi Biodiversity Targets. Ambio 47:427-440 DOI:10.1007/s13280-017-1001-Z.

1195 Long RD, Charles A, Stephenson RL. 2015. Key principles of marine ecosystem-based

1196 management. Marine Policy 57:53-60 DOI: 10.1016/j.marpol.2015.01.013. 
1197 Lotze HK, Coll M, Magera AM, Ward-Paige C, Airoldi L. 2011. Recovery or marine animal

1198 populations and ecosystems. Trends in Ecology \& Evolution 26:595-605 DOI:

1199 10.1016/.j.tree.2011.07.008.

1200 LTER Network. 2018. Available at: https://1ternet.edu/site/lter-network/.Lucifora LO, Barbini

1201 SA, Scarabotti PA, Sabadin DE. 2019. Socio-economic development, scientific research, and

1202 exploitation explain differences in conservation status of marine and freshwater chondrichthyans

1203 among countries. Reviews in Fish Biology \& Fisheries 29:951-964. DOI:10.1007/s11160-019-

1204 09584-w.

1205 Lynch PD, Shertzer KW, Latour RJ. 2012. Performance of methods used to estimate indices of

1206 abundance for highly migratory species. Fisheries Research 125-126:27-39 DOI:

1207 10/1016/j.fishres.2012.02.005.

1208 MacKeracher T, Diedrich A, Simpfendorfer CA. 2018. Sharks, rays and marine protected areas:

1209 A critical evaluation of current perspectives. Fish and Fisheries 20(2):255-267. DOI:

$121010.1111 /$ faf.12337.

1211 Magris RA, Andrello M, Pressey RL, Mouillot D, Dalongeville A, Jacobi MN, Manel S. 2018.

1212 Biologically representative and well-connected marine reserves enhance biodiversity persistence

1213 in conservation planning. Conservation Letters 11: e12439 DOI: 10.1111/conl.12439.

1214 Mamauag SS, Alino PM, Martinez RJS, Muallil RN, Doctor MVA, Dizon EC, Geronimo RC,

1215 Panga FM, Cabral RB. 2013. A framework for vulnerability assessment of coastal fisheries

1216 ecosystems to climate change - Tool for understanding resilience of fisheries (VA-TURF).

1217 Fisheries Research 147:381-393 DOI: 10.1016/J.FISHRES.2013.07.007.

1218 Manel S, Loiseau N, Andrello M, Fietz K, Goñi R, Forcada A, Lenfant P, Kininmonth S, Marcos

1219 C, Marques V, Mallol S, Pérez-Ruzafa A, Breusing C, Puebla O, Mouillot D. 2019. Long-

1220 Distance Benefits of Marine Reserves: Myth or Reality? Trends in Ecology \& Evolution

1221 34(4):342-354. DOI: 10.1016/j.tree.2019.01.002.

1222 Manel S, Loiseau N, Puebla O. 2019. Long-Distance Marine Connectivity: Poorly Understood

1223 but Potentially Important. Trends in Ecology \& Evolution 34(8):688-689. DOI:

1224 10.1016/j.tree.2019.05.011.

1225 Marshall NJ, Kleine DA, Dean AJ. 2012. CoralWatch: Education, monitoring, and sustainability

1226 through citizen science. Frontiers in Ecology and the Environment 10:332-334 DOI:

$122710.1890 / 110266$.

Peer) reviewing PDF | (2019:07:39530:2:0:NEW 21 Jul 2020) 
1228 Marques A, Pereira HM, Krug C., Leadley PW, Visconti P., Januchowski-Hartley SR, Krug RM, 1229 Alkemade R, Bellard C, Cheung WWL, Christensen V, Cooper HD, Hirsch T, Hoft R. van Kolck 1230 J, Newbold T, Noonan-Mooney K, Regan EC, Rondinini C, Sumaila UR, Teh LSL, Walpole M.

1231 2014. A framework to identify enabling and urgent actions for the 2020 Aichi Targets. Basic and 1232 Applied Ecology 15:633-638 DOI: 10.1016/j.baae.2014.09.004.

1233 Martin J-L, Maris V, Simberloff DS. 2016. The need to respect nature and its limits challenges

1234 society and conservation science. Proceedings of the National Academy of Science: USA

1235 113:6105-6112. DOI:10.1073/pnas.1525003113.

1236 Martins APB, Feitosa LM, Lessa RP, Almeida ZS, Heupel M, Silva WM, Tchaicka L, Nunes

1237 JLS. 2018. Analysis of the supply chain and conservation status of sharks (Elasmobranchii:

1238 Superorder Selachimorpha) based on fisher knowledge. PLOS ONE 13:e0193969.

1239 Martinet V, Thebaud O, Rapaport A. 2010. Hare or tortoise? Trade-offs in recovering sustainable

1240 bioeconomic systems. Environmental Modeling and Assessments 15:503-517

1241 DOI:10.1007/s10666-010-9226-2.

1242 Matabos M, Hoeberechts M, Doya C, Aguzzi J, Nephin J, Reimchen T, Leaver S, Marx R,

1243 Branzan Albu A, Fier R, Fernandez-Arcaya U, Juniper S. 2017. Expert, Crowd, Students or

1244 Algorithm: who holds the key to deep-sea imagery 'big data' processing? Methods in Ecology

1245 and Evolution 8: 996-1004 DOI:10.1111/2041-210X.12746.

1246 MCI (Marine Conservation Institute). 2018. Interactive Map. Available at

1247 http://www.mpatlas.org/map/mpas/ (accessed July 2018).

1248 McKinley DC, Miller-Rushing AJ, Ballard HL, Bonney R, Brown H, Cook-Patton SC, Evans

1249 DM, French RA, Parrish JK, Phillips TB, Ryan SF, Shanley LA, Shirk JL, Stepenuck KF,

1250 Weltzin JF, Wiggins A, Boyle OD, Briggs RD, Chapin SF, Hewitt DA, Preuss PW, Soukup MA.

1251 2017. Citizen science can improve conservation science, natural resource management, and

1252 environmental protection. Biological Conservation 208:15-28 DOI:

1253 10.1016/j.biocon.2016.05.015.

1254 McQuatters-Gollop A, Mitchell I, Vina-Herbon C, Bedford J, Addison PFE, Lynam CP, Geetha

1255 PN, Vermeulan EA, Smit K, Bayley DTI, Morris-Webb E, Niner HJ, Otto SA. 2019. From

1256 Science to Evidence - How Biodiversity Indicators Can Be Used for Effective Marine

1257 Conservation Policy and Management. Frontiers in Marine Science 6:109. DOI:

$1258 \quad 10.3389 /$ fmars.2019.00109. 
1259 McWilliam JN, McCauley RD, Erbe C, Parsons MJG. 2017. Soundscape diversity in the Great

1260 Barrier Reef: Lizard Island, a case study. Bioacoustics 27(3): 295-311 DOI:

$126110.1080 / 09524622.2017 .1344930$.

1262 McWilliam M, Hoogenboom MO, Baird AH, Kuo C, Madin JS, Hughes TP. 2018.

1263 Biogeographical disparity in the functional diversity and redundancy of corals. Proceedings of

1264 the National Academy of Sciences 115:3084-3089 DOI:10.1073/pnas.1716643115.

1265 MedPAN \& UNEP-MAP-SPA/RAC, 2016. The 2016 status of Marine Protected Areas in the

1266 Mediterranean main finding. Available at

1267 http://d2ouvy59p0dg6k.cloudfront.net/downloads/medpan_forum_mpa_2016__brochure_a4_en

1268 _web_1_.pdf (accessed 24 July 2018).

1269 Menini E, Van Dover CL. 2019. An atlas of protected hydrothermal vents. Marine Policy

1270 108:103654. DOI: 10.1016/j.marpol.2019.103654.

1271 Mercer J, Kelman I, Alfthan B, Kurvits T. 2012. Ecosystem-Based Adaptation to Climate

1272 Change in Caribbean Small Island Developing States: Integrating Local and External

1273 Knowledge. Sustainability 4:1908-1932 DOI: 10.3390/su4081908.

1274 Merenlender A, Crall A, Drill S, Prysby M, Ballard H. 2016. Evaluating environmental

1275 education, citizen science, and stewardship through naturalist programs. Conservation Biology

1276 30:1255-1265 DOI:10.1111/cobi.12737.

1277 Mizrahi M, Duce S, Pressey RL, Simpfendorfer CA, Weeks R, Diedrich A. 2019. Global

1278 opportunities and challenges for Shark Large Marine Protected Areas. Biological Conservation

1279 234:107-115. DOI:10.1016/j.biocon.201903.026.

1280 Moilanen A. 2007. Landscape zonation, benefits functions and target-based planning: unifying

1281 reserve selection strategies. Biological Conservation 134:571-579.

1282 DOI:10.1016/j.biocon.2006.09.008.

1283 Möller I, Spencer T, French JR, Leggett DJ, and Dixon M. 1999. Wave transformation over salt

1284 marshes: a field and numerical modelling study from North Norfolk, England. Estuarine,

1285 Coastal and Shelf Science 49:411-426 DOI: 10.1006/ecss.1999.0509.

1286 Monczak A, Berry A, Kehrer C, Montie EW. 2017. Long-term acoustic monitoring of fish

1287 calling provides baseline estimates of reproductive timelines in the May River estuary,

1288 southeastern USA. Marine Ecology Progress Series 581:1-19 DOI: 10.3354/meps 12322.

Peer) reviewing PDF | (2019:07:39530:2:0:NEW 21 Jul 2020) 
1289 Morley JW, Selden R, Latour RJ, Frölicher TL, Seagraves RJ, Pinsky ML. 2018. Projecting

1290 shifts in thermal habitat for 686 species on the north American continental shelf. PLoS ONE

1291 13:e0196127. DOI:10.1371.journal.pone.0196127.

1292 Morris JA. 2012. Invasive Lionfish: A Guide to Control and Management. Gulf and Caribbean

1293 Fisheries Institute Special Publication Series Number 1, Marathon, Florida, USA. Available at:

1294 http://lionfish.gcfi.org/manual/InvasiveLionfishGuide_GCFI_SpecialPublicationSeries_Number 1295 1_2012.pdf.

1296 Mouillot D, Parravicini V, Bellwood DR, Leprieur F, Huang D, Cowman P F, and Guilhaumon

1297 F. 2016. Global marine protected areas do not secure the evolutionary history of tropical corals

1298 and fishes. Nature Communications, 7(1), 1-8 DOI: 10.1038/ncomms10359.

1299 Muller-Karger FE, Miloslavich P, Bax NJ, Simmons S, Costello MJ, Sousa Pinto I, Canonico G,

1300 Turner W, Gill M, Montes E, Best BD, Pearlman J, Halpin P, Dunn D, Benson A, Martin CS,

1301 Weatherdon LV, Appeltans W, Provoost P, Klein E, Kelble CR, Miller RJ, Chavez FP, Iken K,

1302 Chiba S, Obura D, Navarro LM, Pereira HM, Allain V, Batten S, Benedetti-Checchi L, Duffy JE,

1303 Kudela RM, Rebelo L-M, Shin Yand Geller G. 2018. Advancing Marine Biological

1304 Observations and Data Requirements of the Complementary Essential Ocean Variables (EOVs)

1305 and Essential Biodiversity Variables (EBVs) Frameworks. Frontiers in Marine Science. 5:211.

1306 DOI: 10.3389/fmars.2018.00211.

1307 Mullineaux LS, Metaxas A, Beaulieu SE, Bright M, Gollner S, Grupe BM, Herrera S, Kellner

1308 JB, Levin LA, Mitarai S, Neubert MG, Thurnherr AM, Tunnicliffe V, Watanabe HK, and Won

1309 Y-J. 2018. Exploring the Ecology of Deep-Sea Hydrothermal Vents in a Metacommunity

1310 Framework. Frontiers in Marine Science 5:49. DOI: 10.3389/fmars.2018.00049.

1311 Munguia-Vega A, Green AL, Suarez-Castillo AN, Espinosa-Romero MJ, Aburto-Oropeza O,

1312 Cisneros-Montemayor AM, Cruz-Piñón G, Danemann G, Giron-Nava A, Gonzalez-Cuellar O,

1313 Lasch C, Mancha-Disneros M, Marinone SG, Moreno-Báez M, Morzaria-Luna H, Reyes-Bonilla

1314 H, Torre J, Turk-Boyer P, Walther M, Weaver AH. 2018. Ecological guidelines for designing

1315 networks of marine reserves in the unique biophysical environment of the Gulf of California.

1316 Reviews in Fish Biology and Fisheries DOI: 10.1007/s11160-018-9529-y.

1317 Murray S, Hee TT. 2019. A rising tide: California's ongoing commitment to monitoring, managing

1318 and enforcing its marine protected areas. Ocean \& Coastal Management 182-104920 DOI:

1319 10.1016/j.ocecoaman.2019.104920

Peer) reviewing PDF | (2019:07:39530:2:0:NEW 21 Jul 2020) 
1320 Nagelkerken I, Blaber SJM, Bouillon S, Green P, Haywood M, Kirton LG, Meynecke J-O,

1321 Pawlik J, Penrose HM, Sasekumar A, Somerfield PJ. 2008. The habitat function of mangroves

1322 for terrestrial and marine fauna: A review. Aquatic Botany 89:155-185. DOI:

1323 10.1016/j.aquabot.2007.12.007.

1324 NEAFC. 2018. Recommendation 19 2014: Protection of VMEs in NEAFC Regulatory Areas, as

1325 Amended by Recommendation 09:2015 and Recommendation 10:2018.

1326 Available at: https://www.neafc.org/system/files/Rec.19-

1327 2014 as amended by 092015 and 102018 fulltext-and-map.pdf

1328 Nicholson E, Fulton EA, Brooks TM, Blanchard R, Leadley P, Metzger JP, Mokany K,

1329 Stevenson S, Wintle BA, Woolley SNC, Barnes M, Watson JEM, Ferrier S. 2019. Scenarios and

1330 Models to Support Global Conservation Targets. Trends in Ecology \& Evolution 34(1):57-68.

1331 DOI: 10.1016/j.tree.2018.10.006.

1332 NMFS (National Marine Fisheries Service) 2017. Annual commercial landing statistics. Silver

1333 Spring, MD: NOAA. www.st.nmfs.noaa.gov/commercial-fisheries/commercial-landings/annual-

1334 landings/index. (Accessed 2 May 2019).

1335 Nyman E. 2018. Protecting the poles: marine living resource conservation approaches in the

1336 Arctic and Antarctic. Ocean \& Coastal Management 151:193-200.

1337 DOI:10.1016/j.ocecoaman.2016.11.006.

1338 O’Neill FG, Mutch K. 2017. Selectivity in Trawl Fishing Gears. Scottish Marine and Freshwater 1339 Science 8:85 DOI:10.4789/1890-1.

1340 Oozeki Y, Inagake D, Saito T, Okazaki M, Fusejima I, Hotai M, Watanabe T, Sugisaki H,

1341 Miyahara M. 2018. Reliable estimation of IUU fishing catch amounts in the northwestern Pacific

1342 adjacent to the Japanese EEZ: Potential for usage of satellite remote sensing images, Marine

1343 Policy 88:64-74 DOI: 10.1016/j.marpol.2017.11.009.

1344 O’Hara CC, Villaseñor-Derbez JC, Ralph GM, Halpern BS. 2019. Mapping status and

1345 conservation of global at-risk marine biodiversity. Conservation Letters 12(4):e12651. DOI:

$1346 \quad 10.1111 /$ conl.12651.

1347 O'Rourke D. 2014. The science of sustainable supply chains. Science 344:1124-1127 DOI:

$1348 \quad 10.1126 /$ science. 1248526.

1349 Orth RJ, Carruthers TJ, Dennison WC, Duarte CM, Fourqurean JW, Heck JR. KL, Randall

1350 Hughes A, Kendrick GA, Judson Kenworthy W, Olyarnik S, Short FT, Waycott M, Williams SL. 
1351 2006. A global crisis for seagrass ecosystems. Bioscience 56:987-996 DOI: 10.1641/0006-

1352 3568(2006)56[987;AGCFSE]2.0CO;2.

1353 OSPAR. 2006. Guidance on developing an ecologically coherent network of OSPAR Marine

1354 Protected Areas. (Reference number 2006-3). Available at:

1355 https://www.ospar.org/documents?d=32377

1356 OSPAR Commission. 2017. OSPAR Intermediate Assessment 2017. Available at

1357 https://oap.ospar.org/en/ospar-assessments/intermediate-assessment-2017/ (accessed 26 August 1358 2018).

1359 Österblom H, Bodin Ö, Rashid Sumaila U, Press AJ. 2014. Reducing illegal fishing in the

1360 Southern Ocean: a global effort. Solutions 4:72-79.

1361 Paling EI, Fonseca M, van Katwijk MM, van Keulen M. 2009. Seagrass restoration. In: Perillo

1362 G, Wolanski E, Cahoon D, Brinson M, eds. Coastal Wetlands: An Integrated Ecosystem

1363 Approach. Amsterdam: Elsevier, 687-713.

1364 Papaioannou, Maria. 2016. The EU - Africa Partnership in the Fight Against IUU Fishing.

1365 [Abstract] African Journal of International and Comparative Law. 24. 158-167. DOI:

1366 10.3366/ajicl.2016.0145.

1367 Pershing A, Alexander MA, Hernandez CMm Kerr LA, Bris LA, Mills KE, Nye JA, Record NR, 1368 Scannell HA, Scott JD, Sherwood GD, Thomas AC. 2015. Slow adaptation in the face of rapid

1369 warming leads to collapse of the Gulf of Maine cod fishery. Science 350: 809-812. DOI:

1370 10.1126/science.aac9819.

1371 Peters JW, Eggleston DB, Puckett BJ, Theuerkauf SJ. 2017. Oyster Demographics in Harvested

1372 Reefs vs. No-Take Reserves: Implications for Larval Spillover and Restoration Success.

1373 Frontiers in Marine Science 4:326. DOI: 10.33389/fmars.2017.00326.

1374 Peterson CH, Grabowski JH, Powers SP. 2003. Estimated enhancement of fish production

1375 resulting from restoring oyster reef habitat: quantitative valuation. Marine Ecology Progress

1376 Series 264. DOI: $10.3354 /$ meps264249.

1377 Petes LE, Howard JF, Helmuth BS, Fly EK. 2014. Science integration into US climate and ocean

1378 policy. Nature Climate Change 4:671-677. DOI: 10.1038/nclimate2312.

1379 Pinheiro HT, Teixeira JB, Francini-Filho RB, Soares-Gomes A, Ferreira CEL, Rocha LA. 2019.

1380 Hope and doubt for the world's marine ecosystems. Perspectives in ecology and conservation 17:

1381 19-25 DOI: 10.1016/j.pecon.2018.11.001.

Peer] reviewing PDF | (2019:07:39530:2:0:NEW 21 Jul 2020) 
1382 Poloczanska ES, Brown CJ, Sydeman WJ, Kiessling W, Schoeman DS, Moore PJ, Brander K,

1383 Bruno JF, Buckley LB, Burrows MT, Duarte CM, Halpern BS, Holding J, Kappel CV, O’Connor

1384 MI, Pandolfi JM, Parmesan C, Schwing F, Thompson SA, Richardson AJ. 2013. Global imprint

1385 of climate change on marine life. Nature Climate Change 3:919-925 DOI:

$138610.1038 /$ nclimate1958.

1387 Powers SP, Peterson CH, Grabowski JH, Lenihan HS. 2009. Success of constructed oyster reefs

1388 in no-harvest sanctuaries: implications for restoration. Marine Ecology Progress Series 389:159-

1389 170. DOI: $10.3354 / \operatorname{meps} 08164$.

1390 Puckett BJ, Eggleston DB. 2012. Oyster Demographics in a Network of No-Take Reserves:

1391 Recruitment, Growth, Survival, and Density Dependence. Marine and Coastal Fisheries 4:605-

1392 627. DOI: 10.1080/19425120.2012.713892.

1393 Puckett BJ, Theuerkauf SJ, Eggleston DB, Guajardo R, Hardy C, Gao J, Leuttich RA. 2018.

1394 Integrating Larval Dispersal, Permitting, and Logistical Factors Within a Validated Habitat

1395 Suitability Index for Oyster Restoration. Frontiers in Marine Science 5:76. DOI:

$139610.3389 /$ fmars.2018.00076.

1397 Ramirez-Llodra E, Tyler PA, Baker MC, Bergstad OA, Clark MR, Escobar E, Levin LA, Menot

1398 L, Rowden AA, Smith CR, and Van Dover CL. 2011. Man and the Last Great Wilderness:

1399 Human Impact on the Deep Sea. PLoS ONE 6:e22588 DOI: 10.1371/journal.pone.0022588.

1400 Rees SE, Foster NL, Langmead O, Pittman S, and Johnson DE. 2018. Defining the qualitative

1401 elements of Aichi Biodiversity Target 11 with regard to the marine and coastal environment in

1402 order to strengthen global efforts for marine biodiversity conservation outlined in the United

1403 Nations Sustainable Development Goal 14. Marine Policy 93:241-250 DOI:

1404 10.1016/j.marpol.2017.05.016.

1405 Rilov G. 2016. Multi-species collapses at the warm edge of a warming sea. Scientific Reports 1406 6:36897 DOI: 10.1038/srep36897.

1407 Rilov G, Fraschetti S, Gissi E, Pipitone C, Badalamenti F, Tamburello L, Menini E, Goriup PD,

1408 Mazaris A, Garrabou J, Benedetti-Cecchi L, Danovaro R, Loiseau C, Claudet J, Katsanevakis S.

1409 2019. A fast-moving target: achieving marine conservation goals under shifting climate and

1410 policies. Ecological Applications e02009 DOI: 10.1002/eap.2009.

1411 Roberts CM, Hawkins JP, Fletcher J, Hands S, Raab K, and Ward S. 2010. Guidance on the size

1412 and spacing of marine protected areas in England. Natural England Commissioned Report

Peer) reviewing PDF | (2019:07:39530:2:0:NEW 21 Jul 2020) 
1413 NECR037. Available at

1414 http://publications.naturalengland.org.uk/publication/46009?category=10006 (accessed 25 July

1415 2018).

1416 Roberts KE, Duffy GA, Cook CN. 2019. Bio-physical models of marine environments reveal

1417 biases in the representation of protected areas. Aquatic Conservation: Marine and Freshwater

1418 Ecosystems 29(3):499-510. DOI: 10.1002/aqc.3003.

1419 Rochette J, Gjerde K, Druel E, Ardron JA, Craw A, Halpin P, Pendleton L, Teleki K, and Cleary

1420 J. 2014. Delivering the Aichi target 11: challenges and opportunities for marine areas beyond

1421 national jurisdiction. Aquatic Conservation: Marine and Freshwater Ecosystems 24:31-43 DOI:

$142210.1002 / \mathrm{aqc} .2507$.

1423 Rodriguez AB, Fodrie FJ, Ridge JT, Lindquist NL, Theuerkauf EJ, Coleman SE, Grabowski JH,

1424 Brodeur MC, Gittman RK, Keller DA, Kenworthy MD. 2014. Nature Climate Change 4: 493-

1425 497. DOI: 10.1038/NCLIMATE2216.

1426 Romañach SS, DeAngelis DL, Koh HL, Li Y, Teh SY, Raja Barizan RS, and Zhai L. 2018.

1427 Conservation and restoration of mangroves: Global status, perspectives, and prognosis. Ocean

1428 and Coastal Management 154:72-82. DOI: 10.1016/j.ocecoaman.2018.01.009.

1429 Saarman E, Gleason M, Ugoretz J, Airamé S, Carr M, Fox E, Frimodig A, Mason T, and

1430 Vasques J. 2013. The role of science in supporting marine protected area network planning and

1431 design in California. Ocean and Coastal Management 74:45-56 DOI:

1432 10.1016/j.ocecoaman.2012.08.021.

1433 Saeedi H, Reimer JD, Brandt MI, Dumais P, Jażdżewska AM, Jeffery NW, Thielen PM, Costello

1434 MJ. 2019. Global marine biodiversity in the context of achieving the Aichi Targets: ways

1435 forward and addressing data gaps. PeerJ 7:e7221. DOI:10.7717/peerj.7221.

1436 Sala E, Lubchenco J, Grorud-Colvert K, Novelli C, Roberts C, and Sumaila U R. 2018.

1437 Assessing real progress towards effective ocean protection. Marine Policy, 91(November 2017),

1438 11-13 DOI: 10.1016/j.marpol.2018.02.004.

1439 Sanchirico JN, Wilen JE. 2005. Optimal spatial management of renewable resources: matching

1440 policy scope to ecosystem scale. Journal of Environmental Economics \& Management 50:23-46

1441 DOI: 10.1016/j.jeem.2004.11.001.

1442 Sarda R, Avila C, Mora J. 2005. A methodological approach to be used in integrated coastal zone

1443 management: The case of the Catalan Coast (Catalonia, Spain). Estuarine, Coastal and Shelf

Peer) reviewing PDF | (2019:07:39530:2:0:NEW 21 Jul 2020) 
1444 Science 62:427-439. DOI: 10.1016/j.ecss.2004.09.028.

1445 Satria F, Sadiyah L, Widodo AA, Wilcox C, Ford JH, Hardesty BD. 2018. Characterizing

1446 transhipment at-sea activities by longline and purse seine fisheries in response to recent policy

1447 changes in Indonesia. Marine Policy 95:8-13 DOI: 10.1016/j.marpol.2018.06.010.

1448 SCBD. 2010. UNEP/CBD/COP/DEC/X/2 Decision adopted by the Conference of the Parties to

1449 the Convention on Biological Diversity at its tenth meeting: X/2 The Strategic Plan for

1450 Biodiversity 2011-2020 and the Aichi Biodiversity Targets. Available at

1451 https://www.cbd.int/decision/cop/default.shtml?id=12268.

1452 SCBD, UNDP, UNEP, FAO and the World Bank. 2016. Biodiversity and the 2030 Agenda for

1453 Sustainable Development: Technical note. Available at https://www.cbd.int/development/

1454 (accessed 26 August 2018).

1455 Schulte DM, Burke RP, Lipcius RN. 2009. Unprecedented Restoration of a Native Oyster

1456 Metapopulation. Science 325: 1124-1128. DOI: 10.1126/science.1176516.

1457 Secretariat of the Convention on Biological Diversity. 2014. Global Biodiversity Outlook 4 -

1458 Summary and Conclusions. Montréal, 20 pages. Available at https://www.cbd.int/GBO4/

1459 (accessed 24 December 2019).

1460 Secretariat of the Convention on Biological Diversity. 2019. Considerations on ecosystem

1461 restoration for the post-2020 global biodiversity framework, including on a possible successor to

1462 Aichi biodiversity target 15. Thematic workshop on ecosystem restoration for the post-2020

1463 global biodiversity framework, Rio de Janeiro, 6-8 November 2019. Contributors: Bodin B,

1464 Brancalion PHS, Chazdon RL, Cooper D, Crouzeilles R, Dreyer N, Funge-Smith S, Janishevski

1465 L, Leite I, Miles L, Scaramuzza CAM, Shestakov1 A, Strassburg BBN, Thornton H, Vieira RRS.

1466 Available at: https://www.cbd.int/doc/c/fcd6/bfba/38ebc826221543e322173507/post2020-ws-

1467 2019-11-03-en.pdf (accessed 01 February 2020).

1468 Serdy A. 2016. Implementing Article 28 of the UN Fish Stocks Agreement: the first review of a

1469 conservation measure in the South Pacific Regional Fisheries Management Organization. Ocean

1470 Development \& International Law 47:1-28 DOI: 10.1080/00908320.2016.1124482.

1471 Sherman KD, Shultz AD, Dahlgren CP, Thomas C, Brooks E, Brooks A, Brumbaugh DR,

1472 Gittens L, Murchie KJ. 2018. Contemporary and emerging fisheries in The Bahamas-

1473 Conservation and management challenges, achievements and future directions. Fisheries

1474 Management and Ecology 00:319-331 DOI: 10.1111/fme.12299.

Peer) reviewing PDF | (2019:07:39530:2:0:NEW 21 Jul 2020) 
1475 Shepard CC, Crain CM, Beck MW. 2011. The protective role of coastal marshes: A systematic

1476 review and meta-analysis. PLoS ONE 6:e27374 DOI: 10.1371/journal.pone.0027374.

1477 Shiffman DS, Hueter RE. 2017. A United States shark fin ban would undermine sustainable

1478 shark fisheries. Marine Policy 85:138-140 DOI: 10.1016/j.marpol.2017.08.026.

1479 Smale DA, Burrows MT, Evans AJ, King NJ, Yunnie ALE, Moore PJ. 2016. Linking

1480 environmental variables with regional-scale variability in ecological structure and standing stock

1481 of carbon within kelp forests in the United Kingdom. Marine Ecology Progress Series 542:79-

148295 DOI: 10.3354/meps11544.

1483 Smith BG. 2008. Developing sustainable food supply chains. Philosophical Transactions of the

1484 Royal Society B: Biological Sciences 363:849-861 DOI: 10.1098/rstb.2007.2187.

1485 Sousa E, Quintino V, Palhas J, Rodrigues AM, Teixeira J .2016. Can environmental education

1486 actions change public attitudes? An example using the pond habitat and associated biodiversity.

1487 PLoS ONE 11:e0154440 DOI: 10.1371/journal.pone.0154440.

1488 Spalding MD, Ruffo S, Lacambra C, Meliane I, Hale LZ, Shepard CC, Beck MW. 2014. The

1489 role of ecosystems in coastal protection: Adapting to climate change and coastal hazards. Ocean

1490 and Coastal Management 90:50-57. DOI: 10.1016/j.ocecoaman.2013.09.007.

1491 SponGES. 2018. Available at: http://www.deepseasponges.org/.

1492 Steneck RS, Graham MH, Bourque BJ, Bruce J, Corbett D, Erlandson JM, Estes JA, Tegner MJ.

1493 2002. Kelp forest ecosystems: biodiversity, stability, resilience and future. Environmental

1494 Conservation 29:436-459 DOI: 10.1017/S0376892902000322.

1495 Stevenson SL, Woolley SNC, Barnett J, Dunstan P. 2019. Testing the presence of marine

1496 protected areas against their ability to reduce pressures on biodiversity. Conservation Biology.

1497 Accepted. DOI: 10.1111/cobi.13429.

1498 Swimmer Y, Suter J, Arauz R, Bigelow K, López A, Zanela I, Bolaños A, Ballestero J, Suárez R, 1499 Wang J, Boggs C. 2011. Sustainable fishing gear: the case of modified circle hooks in a Costa

1500 Rican longline fishery. Marine Biology 158: 757-767 DOI: 10.1007/s00227-010-2604-4.

1501 Stuart F, Hernández-Velasco A, Suarez-Castillo A, Melo FF, Rojo M, Sáenz-Arroyo A, Weaver

1502 AH, Cudney-Bueno R, Micheli F, Torre J. 2019. From fishing fish to fishing data: the role of

1503 artisanal fishers in conservation and resource management in Mexico. In: Salas S, Barragán-

1504 Paladines M, Chuenpagdee R (eds) Viability and Sustainability of Small-Scale Fisheries in Latin 
1505 American and the Caribbean. MARE Publication Series Springer, Cham 19:151-175

1506 DOI:10.1007/978-3-319-76078-0_7.

1507 Suzuki K, Yoshida K, Watanabe H, Yamamoto H. 2018. Mapping the resilience of

1508 chemosynthetic communities in hydrothermal vent fields. Scientific Reports 8:9364. DOI:

1509 10.1038/s41598-018-27596-7.

1510 Tallman RF, Roux MJ, Martin ZA. 2019. Governance and assessment of small-scale data-limited

1511 Arctic Charr fisheries using productivity-susceptibility analysis coupled with life history

1512 invariant models. Marine Policy 101:1887-197. DOI:10.1016/j.marpol.2017.11.032.

1513 Teh SLL, Cheung WWL, Christensen V, Sumaila UR. 2018. Can we meet the target? Status and

1514 future trends for fisheries sustainability. Current Opinion in Environmental Sustainability

1515 29:118-130 DOI: 10.1016/j.cosust.2018.02.006.

1516 Teh LSL, Teh LCL, Sumaila UR. 2013. A global estimate of the number of coral reef fishers.

1517 PLOS ONE 8:e65397 DOI: 10.1371/journal.pone.0065397.

1518 Theobald EJ, Ettinger AK, Burgess HK, DeBey LB, Schmidt NR, Froehlich HE, Wagner C,

1519 HilleRisLambers J, Tewksbury J, Harsch MA, Parrish JK. 2015. Global change and local

1520 solutions: Tapping the unrealized potential of citizen science for biodiversity research. Biological

1521 Conservation 181:236-244 DOI: 10.1016/J.BIOCON.2014.10.021.

1522 Theuerkauf SJ, Eggleston DB, Puckett BJ. 2019. Integrating ecosystem services considerations

1523 within a GIS-based habitat suitability index for oyster restoration. PLoS ONE 14. DOI

1524 10.1371/journal.pone.0210936.

1525 Tittensor DP, Walpole M, Hill SLL, Boyce DG, Britten GL, Burgess ND, Butchart SHM,

1526 Leadley PW, Regan EC, Alkemade R, Baumung R, Bellard C, Bouwman L, Bowles-Newark NJ,

1527 Chenery AM, Cheung WWL, Christensen V, Cooper HD, Crowther AR, Dixon MJR, Galli A,

1528 Gaveau V, Gregory RD, Gutierrez NL, Hirsch TL, Höft R, Januchowski-Hartley SR, Karmann

1529 M, Krug CB, Leverington FJ, Loh J, Lojenga RK, Malsch K, Marques A, Morgan DHW,

1530 Mumby PJ, Newbold T, Noonan-Mooney K, Pagad SN, Parks BC, Pereira HM, Robertson T,

1531 Rondinini C, Santini L, Scharlemann JPW, Schindler S, Sumaila UR, Teh LSL, van Kolck J,

1532 Visconti P, and Ye Y. 2014. A mid-term analysis of progress toward international biodiversity

1533 targets. Science 346(6206):241-244 DOI: 10.1126/science.1257484.

1534 Tuya F, Cacabelos E, Duarte P, Jacinto D, Castro J, Silva T, Bertocci I, Franco J, Arenas F, Coca

1535 J, Wernberg T. 2012. Patterns of landscape and assemblage structure along a latitudinal gradient 
1536 in ocean climate. Marine Ecology Progress Series 466:9-19 DOI:10.3354/meps09941.

1537 UNEP. 2006. Marine and coastal ecosystems and human well- being: a synthesis report based on

1538 the findings of the Millennium Ecosystem Assessment. Available at: http://www.unep.org/

1539 pdf/Completev6_LR.pdf

1540 UNEP-WCMC and IUCN. 2019. Marine Protected Planet [On-line], [February, 2020],

1541 Cambridge, UK: UNEP-WCMC and IUCN. Available at: www.protectedplanet.net (accessed 02

1542 February 2020).

1543 United Nations. 2017. Report of the Secretary-General, "Progress towards the Sustainable

1544 Development Goals", E/2017/66. Available at https://sustainabledevelopment.un.org/sdg14

1545 (accessed 24 December 2019).

1546 Valiela I, Kinney E, Culbertson J, Peacock E, Smith S. 2009. Global Losses of Mangroves and

1547 Salt Marshes. In: Duarte CM, ed. Global Loss of Coastal Habitats Rates, Causes and

1548 Consequences. Bilbao: Fundacion BBVA, 107-142.

1549 Van Dover CL, Smith CR, Ardron J, Dunn D, Gjerde K, Levin L, and Smith S. 2012.

1550 Designating networks of chemosynthetic ecosystem reserves in the deep sea. Marine Policy

1551 36:378-381 DOI: 10.1016/j.marpol.2011.07.002.

1552 van Gemert R, Andersen KH. 2018. Challenges to fisheries advice and management due to stock

1553 recovery. ICES Journal of Marine Science 75(6): 1864-1870. DOI: 10.1093/icesjms/fsy084.

1554 van Katwijk MM, Thorhaug A, Marbà N, Orth RJ, Duarte CM, Kendrick GA, Althuizen IH,

1555 Balestri E, Bernard G, Cambridge ML, Cunha A, Durance C, Giesen W, Han Q, Hosokawa S,

1556 Kiswara W, Komatsu T, Lardicci C, Lee K, Meinesz A, Nakaoka M, O'Brien KR, Paling EI,

1557 Pickerell C, Ransijn AM, Verduin JJ, Österblom H. 2016. Global analysis of seagrass

1558 restoration: the importance of large-scale planting. Journal of Applied Ecology 53:567-578 DOI:

1559 10.1111/1365-2664.12562.

1560 van Oppen MJH, Gates RD, Blackall LL, Cantin N, Chakravarti LJ, Chan WY, Cormick C,

1561 Crean A, Damjanovic K, Epstein H, Harrison PL, Jones TA, Miller M, Pears RJ, Peplow LM,

1562 Raftos DA, Schaffelke B, Stewart K, Torda G, Wachenfeld D, Weeks AR, Putnam HM. 2017.

1563 Shifting paradigms in restoration of the world's coral reefs. Global Change Biology. DOI:

1564 10.1111/gcb.13647. 
1565 Veiga-Malta T, Feekings J, Herrmann B, Krag LA. 2018. When is enough, enough? Quantifying 1566 trade-offs between information quality and sampling effort for fishing gear selectivity data. PLoS

1567 ONE 13:e0199655 DOI: 10.1371/journal.pone.0199655.

1568 Verdura J, Sales M, Ballesteros E, Cefalì ME, Cebrian, E. 2018. Restoration of a canopy-

1569 forming alga based on recruitment enhancement: methods and long-term success assessment.

1570 Frontiers in plant science, 9, 1832. DOI: 10.3389/fpls.2018.01832.

1571 Vert-pre KA, Amoroso RO, Jensen OP, Hilborn R. 2013. Frequency and

1572 intensity of productivity regime shifts in marine fish stocks. Proceedings of the National

1573 Academy of Sciences 110:1779-1784 DOI: 10.1073/pnas/1214879110.

1574 Villaseñor-Derbez, J. C., Lynham, J., \& Costello, C. (2020). Environmental market design for

1575 large-scale marine conservation. Nature Sustainability, 1-7.

1576 Watson JEM, Dudley N, Segan DB, Hockings M. 2014. The performance and potential of

1577 protected areas. Nature, 515(7525): 67-73. DOI: $10.1038 /$ nature13947.

1578 Waycott M, Duarte CM, Carruthers TJB, Orth RJ, Dennison WC, Olyarnik S, Calladine A,

1579 Fourqurean JW, Heck KL, Hughes AR, Kendrick GGA, Kenworthy WJ, Short FT, Williams

1580 SW. 2009. Accelerating loss of seagrass across the globe threatens coastal ecosystems.

1581 Proceedings of the National Academy of Sciences 106:12377-12381 DOI:

1582 10.1073/pnas.0905620106.

1583 Williams A, Schlacher TA, Rowden AA, Althaus F, Clark MR, Bowden DA, Stewart R, Bax NJ,

1584 Consalvey M, Kloser RJ. 2010. Seamount megabenthic assemblages fail to recover from

1585 trawling impacts. Marine Ecology 31:183-199. DOI:10.1111/j.1439-0485.2010.00385.x.

1586 Wood G, Marzinelli EM, Coleman MA, Campbell AH, Santini NS, Kajlich L, Verdura J, Wodak

1587 J, Steinberg PD, Vergés A. 2019. Restoring subtidal marine macrophytes in the Anthropocene:

1588 trajectories and future-proofing. Marine and Freshwater Research 70: 936-951. DOI:

1589 10.1071/MF18226.

1590 World Bank. 2017. The Potential of the Blue Economy: Increasing Long-term Benefits of the

1591 Sustainable Use of Marine Resources for Small Island Developing States and Coastal Least

1592 Developed Countries. World Bank.

1593 Xuereb A, D'Aloia CC, Daigle RM, Andrello M, Dalongeville A, Manel S, Mouillot D,

1594 Guichard F, Côté IM, Curtis JMR, Bernatchez L, Fortin M-J. 2019. Marine Conservation and 
1595 Marine Protected Areas. In: Oleksiak M, Rajora O (eds.) Population Genomics: Marine

1596 Organisms. Population Genomics. Springer, Cham.

1597 Yinglin W, Ling X, Shiang-Lin H, Ping L, Zengwei Y, Wenhua L. 2018. Using social media to

1598 strengthen public awareness of wildlife conservation. Ocean and Coastal Management 153:76-

1599 83_DOI: 10.1016/j.ocecoaman.2017.12.010.

1600 Zafra-Calvo N, Garmendia E, Pascual U, Palomo I, Gross-Camp M, Brockington D, Cortes-

1601 Vasquez J-A, Coolsaet B, Burgess ND. 2019. Progress toward Equitably Managed Protected

1602 Areas in Aichi Target 11: A Global Survey. BioScience 69(3):191-197. DOI:

1603 10.1093/biosci/biy143.

1604 Zeng C, Clark MR, Rowden AA, Kelly M, Gardner JPA. 2019. The use of spatially explicit

1605 genetic variation data from four deep-sea sponges to inform the protection of Vulnerable Marine

1606 Ecosystems. Scientific Reports 9:5482. DOI: 10.1038/s41598-019-41877-9.

1607 Zenetos A, Koutsogiannopoulos D, Ovalis P, Poursanidis D. 2013. The role played by citizen

1608 scientists in monitoring marine alien species in Greece. Cahiers de Biologie Marine 54:419-426.

1609 Zostera Experimental Network. 2012. Available at: http://zenscience.org/.

1610 Zu Ermgassen PSE, Spalding MD, Blake B, Coen LD, Dumbauld B, Geiger S, Grabowski JH,

1611 Grizzle R, Luckenbach M, McGraw K, Rodney W, Ruesink JL, Powers SP, Brumbaugh R. 2012.

1612 Historical ecology with real numbers: past and present extent and biomass of an imperiled

1613 estuarine habitat. Proceedings of the Royal Society B 279. DOI:10.1098/rspb.2012.0313. 


\section{Table $\mathbf{1}$ (on next page)}

Table 1: Reviewed Aichi Biodiversity Targets (SCBD, 2010). 
1 Table 1: Reviewed Aichi Biodiversity Targets (SCBD, 2010).

\begin{tabular}{|c|c|c|}
\hline Target & Strategic goal & Description \\
\hline 6 & $\begin{array}{l}\text { B: Reduce the } \\
\text { direct pressures } \\
\text { on biodiversity } \\
\text { and promote } \\
\text { sustainable use }\end{array}$ & $\begin{array}{l}\text { By } 2020 \text { all fish and invertebrate stocks and aquatic plants are } \\
\text { managed and harvested sustainably, legally and applying } \\
\text { ecosystem based approaches, so that overfishing is avoided, } \\
\text { recovery plans and measures are in place for all depleted species, } \\
\text { fisheries have no significant adverse impacts on threatened species } \\
\text { and vulnerable ecosystems and the impacts of fisheries on stocks, } \\
\text { species and ecosystems are within safe ecological limits. }\end{array}$ \\
\hline 11 & $\begin{array}{l}\text { C: Improve the } \\
\text { status of } \\
\text { biodiversity by } \\
\text { safeguarding } \\
\text { ecosystems, } \\
\text { species and } \\
\text { genetic } \\
\text { diversity }\end{array}$ & $\begin{array}{l}\text { By } 2020 \text {, at least } 17 \text { per cent of terrestrial and inland water, and } 10 \\
\text { per cent of coastal and marine areas, especially areas of particular } \\
\text { importance for biodiversity and ecosystem services, are conserved } \\
\text { through effectively and equitably managed, ecologically } \\
\text { representative and well-connected systems of protected areas and } \\
\text { other effective area-based conservation measures, and integrated } \\
\text { into the wider landscape and seascapes. }\end{array}$ \\
\hline 15 & $\begin{array}{l}\text { D: Enhance the } \\
\text { benefits to all } \\
\text { from } \\
\text { biodiversity } \\
\text { and ecosystem } \\
\text { services. }\end{array}$ & $\begin{array}{l}\text { By } 2020, \text { ecosystem resilience and the contribution of biodiversity } \\
\text { to carbon stocks has been enhanced, through conservation and } \\
\text { restoration, including restoration of at least } 15 \text { per cent of degraded } \\
\text { ecosystems, thereby contributing to climate change mitigation and } \\
\text { adaptation and to combating desertification. }\end{array}$ \\
\hline 19 & $\begin{array}{l}\text { E: Enhance } \\
\text { implementation } \\
\text { through } \\
\text { participatory } \\
\text { planning, } \\
\text { knowledge } \\
\text { management }\end{array}$ & $\begin{array}{l}\text { By } 2020, \text { knowledge, the science base and technologies relating to } \\
\text { biodiversity, its values, functioning, status and trends, and the } \\
\text { consequences of its loss, are improved, widely shared and } \\
\text { transferred, and applied. }\end{array}$ \\
\hline
\end{tabular}




\begin{tabular}{|l|l|l|}
\hline $\begin{array}{l}\text { and capacity } \\
\text { building }\end{array}$ & \\
\hline
\end{tabular}

2

3 


\section{Table 2 (on next page)}

Table 2: Examples of the ecosystem services provided by coral reef, mangrove, seagrass, seaweed forest, saltmarsh, and oyster reef habitats. 
1 Table 2: Examples of the ecosystem services provided by coral reef, mangrove, seagrass, 2 seaweed forest, saltmarsh, and oyster reef habitats.

\begin{tabular}{|c|c|}
\hline Habitat & Services \\
\hline Cor & $\begin{array}{l}\text { Coastal protection (Ferrario et al., 2014; Spalding et al., 2014); climate } \\
\text { change mitigation (Spalding et al., 2014); food provision (Teh \& } \\
\text { Sumaila, 2013); nutrient cycling; primary productivity; habitat provision } \\
\text { (McWilliam et al., 2018); support of high biodiversity (Bellwood, Hoey } \\
\text { \& Choat, 2003; Fisher et al., 2015). }\end{array}$ \\
\hline Mar & $\begin{array}{l}\text { Carbon sequestration (Duarte et al., 2005; Gress et al., 2017); coastal } \\
\text { protection and climate change mitigation (Spalding et al., 2014); habitat } \\
\text { provision (Nagelkerken et al., 2008; Kimirei et al., 2013). }\end{array}$ \\
\hline $\begin{array}{l}\text { Seaweed } \\
\text { forests }\end{array}$ & $\begin{array}{l}\text { Primary production; nutrient cycling; habitat provision; food provision; } \\
\text { coastal defence (Dayton, 1985; Steneck et al., 2002; Smale et al., 2015); } \\
\text { and potentially carbon sequestration (Krause-Jensen \& Duarte, 2016). }\end{array}$ \\
\hline Seagrass beds & $\begin{array}{l}\text { Carbon sequestration (Duarte et al., 2005; Fourqurean et al., 2012); } \\
\text { coastal protection (Fonseca \& Cahalan, 1992); primary productivity; food } \\
\text { provision; habitat provision; support of high biodiversity (Duarte \& } \\
\text { Chiscano, 1999). }\end{array}$ \\
\hline Saltmarshes & $\begin{array}{l}\text { Carbon sequestration (Chmura et al., 2003; Duarte et al., 2005; Drake et } \\
\text { al., 2015); coastal protection (Möller et al., 1999; Shepard, Crain \& Beck } \\
\text { 2011; Spalding et al., 2014); climate change mitigation (Spalding et al., } \\
\text { 2014); habitat provision (Barbier et al., 2011). }\end{array}$ \\
\hline Oyster reefs & $\begin{array}{l}\text { Coastal protection and sediment stabilisation (Rodriguez et al., 2014; La } \\
\text { Peyre et al., 2015); nutrient cycling and water filtration (zu Ermgassen et } \\
\text { al., 2012; Kellog et al., 2014); food and habitat provision (Peterson et al., } \\
\text { 2003; Grabowski et al., 2012; Gilby et al., 2018); commercial and } \\
\text { recreational harvest (NMFS, 2017). }\end{array}$ \\
\hline
\end{tabular}

